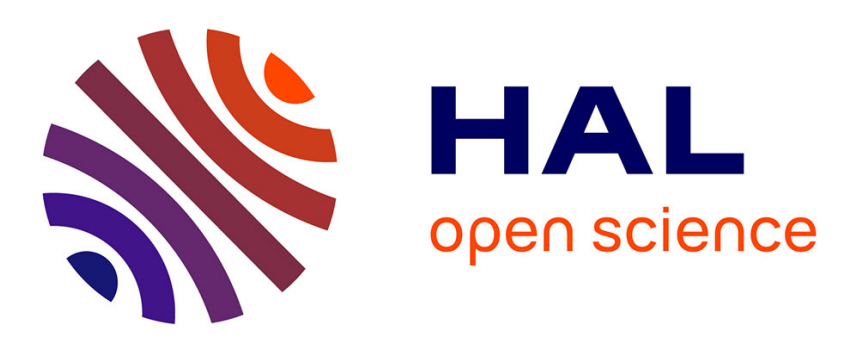

\title{
Simulation and optimization of the removal of toluene in air by ozonation with a catalytic open-cell foam
}

\author{
A. Cabrol, A. Lejeune, Ronan Lebullenger, A. Denicourt-Nowicki, A. \\ Roucoux, A. Couvert, Pierre-Francois Biard
}

\section{- To cite this version:}

A. Cabrol, A. Lejeune, Ronan Lebullenger, A. Denicourt-Nowicki, A. Roucoux, et al.. Simulation and optimization of the removal of toluene in air by ozonation with a catalytic open-cell foam. Chemical Engineering Research and Design, 2021, 168, pp.453-464. 10.1016/j.cherd.2021.02.025 . hal03196091

\section{HAL Id: hal-03196091 \\ https://hal.science/hal-03196091}

Submitted on 21 Apr 2021

HAL is a multi-disciplinary open access archive for the deposit and dissemination of scientific research documents, whether they are published or not. The documents may come from teaching and research institutions in France or abroad, or from public or private research centers.
L'archive ouverte pluridisciplinaire HAL, est destinée au dépôt et à la diffusion de documents scientifiques de niveau recherche, publiés ou non, émanant des établissements d'enseignement et de recherche français ou étrangers, des laboratoires publics ou privés. 


\section{Simulation and optimization of the removal of toluene in air by ozonation with a catalytic open-cell foam}

Audrey Cabrol a, Antoine Lejeune ${ }^{a^{*}}$, Ronan Lebullenger ${ }^{\mathrm{b}}$, Audrey Denicourt-Nowicki ${ }^{\mathrm{b}}$, Alain Roucoux ${ }^{\mathrm{b}}$, Annabelle Couvert ${ }^{\mathrm{b}}$, Pierre-François Biard ${ }^{\mathrm{b}}$

${ }^{\text {a }}$ SATT Ouest Valorisation, 14C Rue du Patis Tatelin, 35700 Rennes

${ }^{\mathrm{b}}$ Univ Rennes, Ecole Nationale Supérieure de Chimie de Rennes, CNRS, ISCR (Institut des Sciences Chimiques de Rennes) - UMR 6226, F-35000, Rennes, France

* Corresponding author: Antoine Lejeune - anlejeun@gmail.com

Graphical abstract

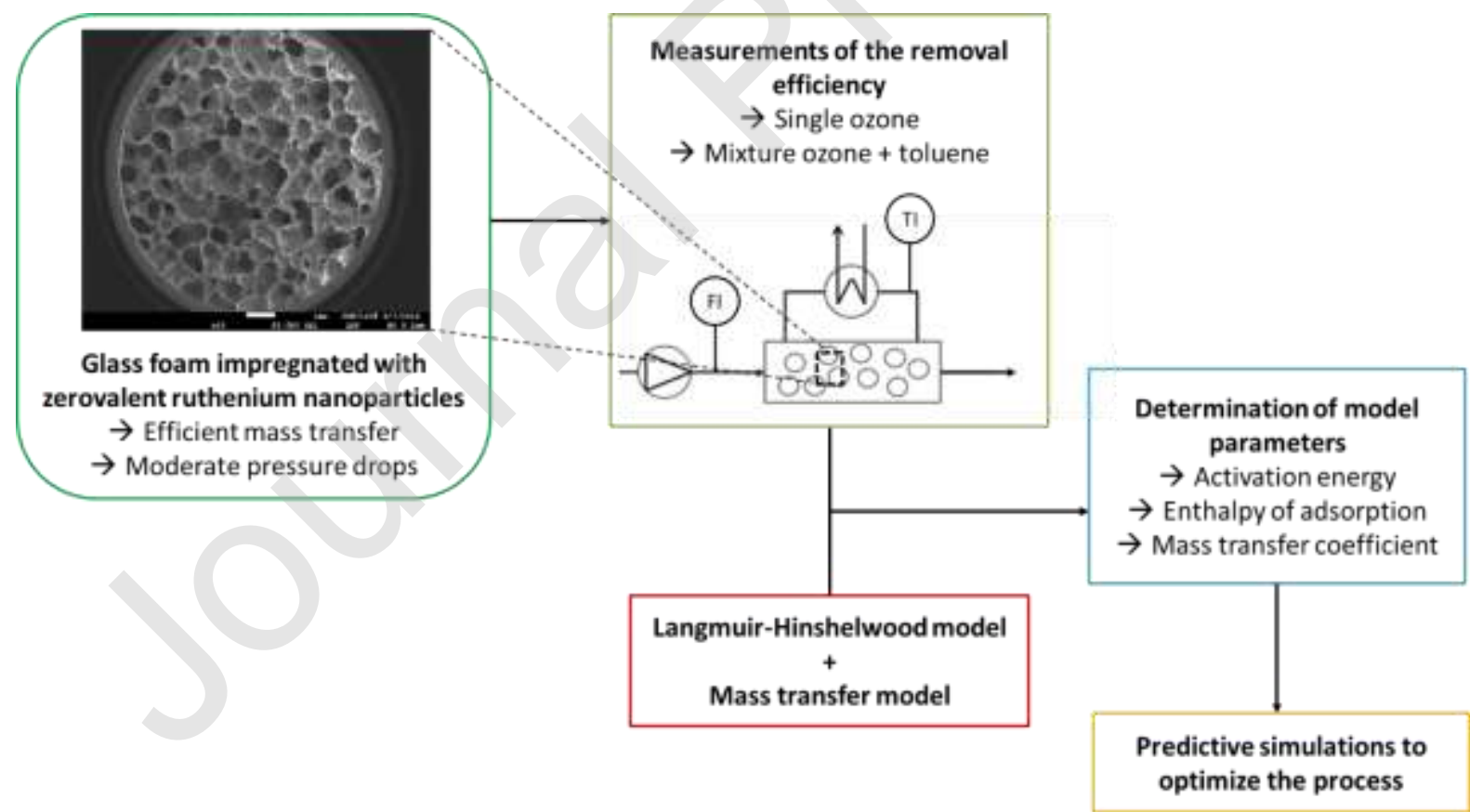




\title{
Highlights:
}

- A ruthenium-doped glass foam was used for the abatement of VOCs by catalytic ozonation

- The removal of toluene was modelled considering a Langmuir-Hinshelwood mechanism

- Predictive simulations allowed to optimize the process efficiency

\begin{abstract}
A heterogeneous catalyst, composed of an open-cell glass foam support impregnated with zerovalent ruthenium nanoparticles (loading around $0.1 \mathrm{wt} . \%$ ), was used to remove toluene in air by catalytic ozonation. Experiments with lab-designed 2-6 cm length and $1.6 \mathrm{~cm}$ diameter catalysts were performed. A model based on the Langmuir-Hinshelwood mechanism, coupled with mass transfer limitations and including competitive effects between toluene and ozone, was designed. It accurately fits experimental data gathered at various temperatures $\left(30-90^{\circ} \mathrm{C}\right)$, gas velocities $\left(0.0025-0.017 \mathrm{~m} . \mathrm{s}^{-1}\right)$ and inlet ozone concentrations (6.4-11.2 g.m $\left.\mathrm{m}^{-3}\right)$. The removal of ozone and toluene was mainly ruled by the ozone concentration at low concentrations while the adsorption competition becomes significant at high ozone concentrations.

Predictive simulations, at $1.0 \mathrm{~g} \cdot \mathrm{m}^{-3}$ inlet toluene concentration, were compared in terms of investment cost, operating cost and process performances. The results highlighted the complexity of the process, which involves antagonist aims between toluene removal and the design of a compact and energy-efficient reactor. With the best operating conditions $\left(90^{\circ} \mathrm{C}\right.$ and 46 g.m $\mathrm{m}^{-3}$ ozone inlet concentration), the removal of toluene reached $88 \%$ (removal rate of
\end{abstract}


$0.25 \mathrm{~g} \cdot \mathrm{m}^{-3} \cdot \mathrm{s}^{-1}$ ) with a high ozone degradation $(97 \%)$ in a moderate reactor length of $0.11 \mathrm{~m}$. These good performances associated to the low cost of the catalyst's synthesis make it an efficient alternative for the removal of pollutants from air.

\section{Keywords}

Air treatment; Catalytic ozonation; Toluene; Modeling; Predictive simulations

\section{Glossary}

$\mathrm{A}^{\prime} \quad$ Constant dealing with the mass transfer efficiency $\left(\mathrm{m}^{-1}\right)$

$\mathrm{A}_{0, \mathrm{i}} \quad$ Pre-exponential factor for removal of species $\mathrm{i}\left(\mathrm{mol} \cdot \mathrm{m}^{-3} \cdot \mathrm{s}^{-1}\right)$

$\mathrm{a}_{\mathrm{v}} \quad$ Active specific surface area of the catalyst $\left(\mathrm{m}^{-1}\right)$ 


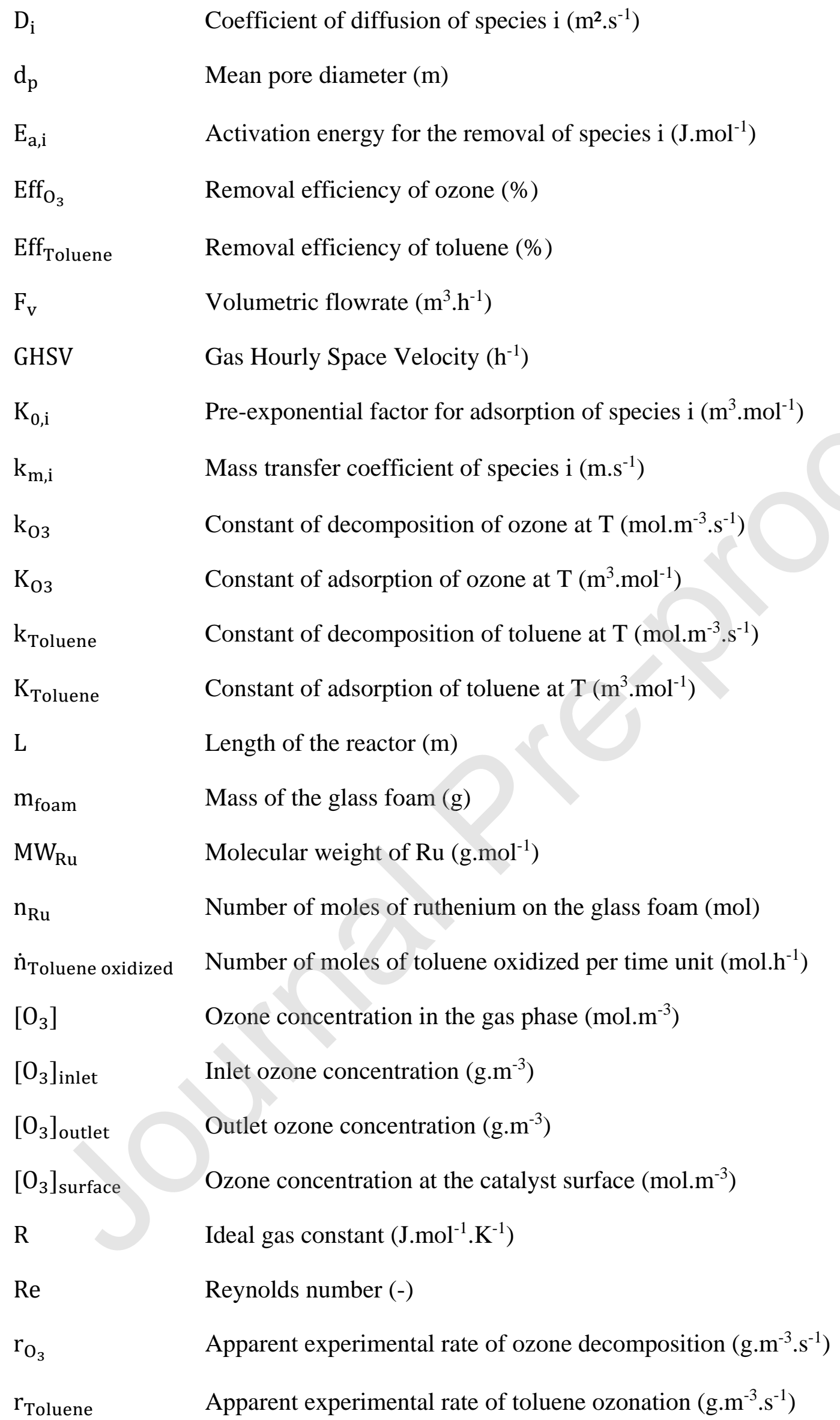




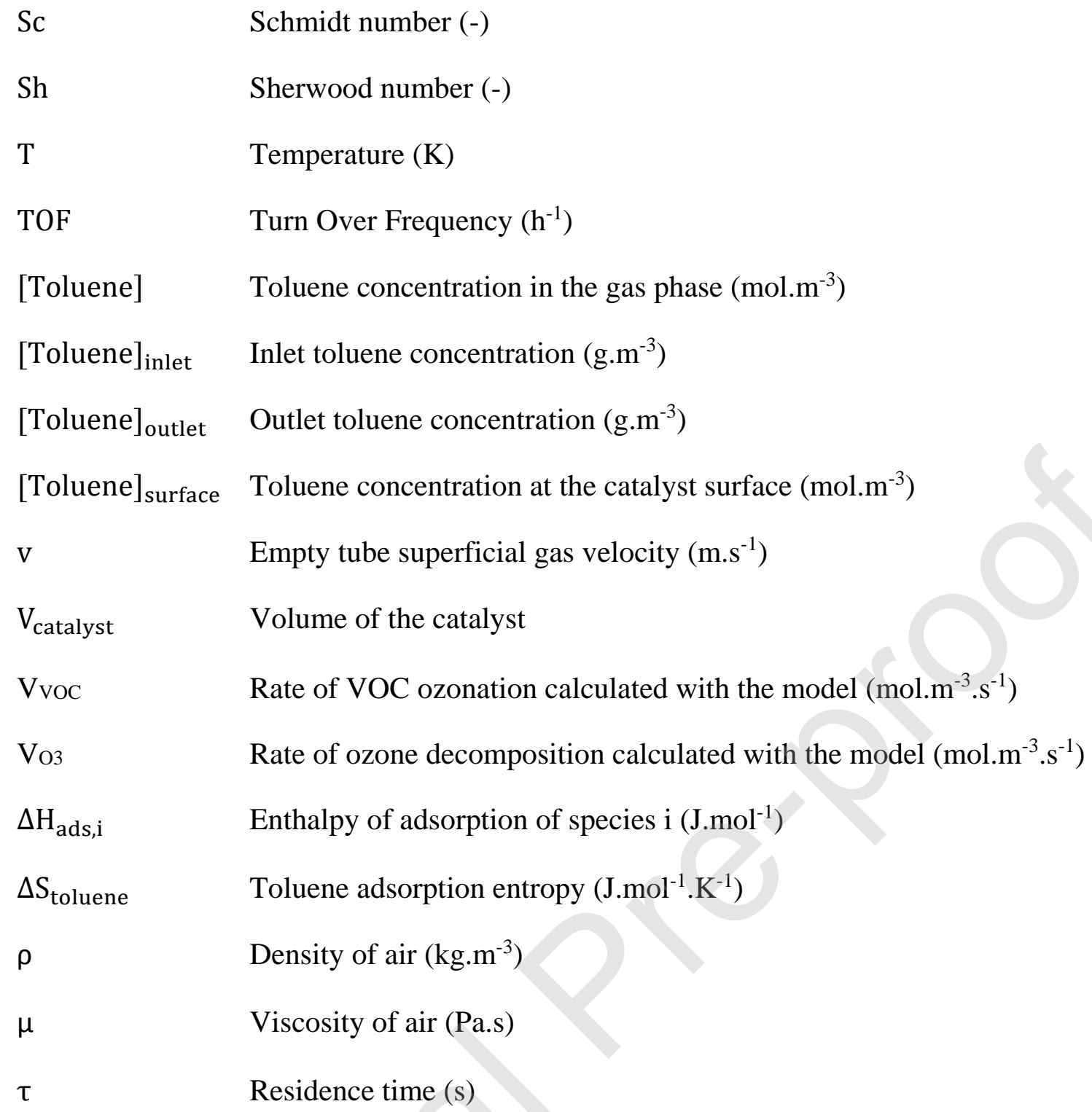

\section{Introduction}

The development of efficient and eco-friendly processes for air treatment remains of high importance since many studies highlighted the detrimental effect of some pollutants in air for human health (Huang et al., 2014; Guo et al., 2004). A particular attention has to be paid to Volatile Organic Compounds (VOCs) presumed to be responsible for human diseases (Lerner et al., 2012). Thermal oxidation has shown to be very efficient for the removal of a large range of VOCs at high concentrations and volumes to treat (Shahzad Kamal et al., 2016), but still requires high temperatures (around $1,000^{\circ} \mathrm{C}$ ), and thus a very high energy consumption. To overcome this issue, catalytic oxidation allows decreasing the involved temperature of hundreds of degrees due to the catalyst that lowers the energy of activation of the reaction (He et al., 2019; Xu et al., 2017; Meille, 2006). The optimized temperatures to fully remove some 
VOCs ranged between $150^{\circ} \mathrm{C}$ and $400^{\circ} \mathrm{C}$ depending on the concentration and type of VOC (Shahzad Kamal et al., 2016; Liotta, 2010).

In order to follow this trend of low involved temperatures, catalytic ozonation can also be used, using ozone instead of oxygen as a more powerful oxidant (He et al., 2019; Huang et al., 2015). Actually, the use of ozone permits the easy formation of reactive oxygen species on the surface of the catalyst which play a major role in VOC destruction (Sano et al., 2006). Even if energy is required to produce ozone, it also allows working under milder conditions close to room temperature or around $100^{\circ} \mathrm{C}$ at the most (Sano et al., 2006). Some studies have already highlighted the potential of catalytic ozonation with several heterogeneous catalysts to remove VOCs (Huang et al., 2015; Rezaei et al., 2013; Einaga et al., 2013; Stoyanova et al., 2006; Changsuphan et al., 2012; Xi et al., 2005; Rezaei and Soltan, 2012; Reed et al., 2006; Einaga and Futamura, 2007; Sekiguchi et al., 2017). Particular attention was paid to both the influence of the type of active catalytic species and catalyst lifetime, a key point for industrial implementation, while the behavior of ozone at the reactor outlet was few commented or even sometimes missing. The efficient removal of ozone is however a prerequisite for the innocuity of the process and for the modelling and sizing of the reactor, at least if no post-treatment is considered.

In this study, a catalytic glass foam was used to remove VOCs from air by catalytic ozonation for the first time. Catalytic foams are known to achieve efficient mass and heat transfers (Bianchi et al., 2015; Giani et al., 2005). The catalyst used here is composed of a glass foam support, mainly synthesized with recycled glass and impregnated with zerovalent metal nanoparticles at a low metal loading of $0.1 \mathrm{wt} \%$ in water and mild conditions without washcoating (Biard et al., 2017; Lejeune et al., 2020a). Its eco-friendly synthesis made it an interesting alternative to conventional ceramic and metallic foams that need expensive raw materials and/or high cost for their synthesis. Catalytic glass foams have fully been characterized in terms of structure, pressure drops, hydrophobicity and surface charge (Lejeune et al., 2020a) and their thermal resistance up to $550^{\circ} \mathrm{C}$ was also proved (Lejeune et al., 2020b). Good activity was found with ruthenium nanoparticles for ozone decomposition at room temperature and inlet concentration of 9 g.m $\mathrm{m}^{-3}$ (Lejeune et al., 2020a). The efficiency of ruthenium for oxidation had also been demonstrated for fine chemistry applications (Rauchdi et al., 2018; Watson et al., 2009; Lebedeva et al., 2010; Axet and Philippot, 2020). Considering the lowest cost of ruthenium compared to other noble metals ( $\mathrm{Rh}, \mathrm{Pt}$ and $\mathrm{Pd}$ especially), it makes it an interesting solution for oxidation processes. With the rutheniumdoped glass foams, the removal of several VOCs (ethanol, acetone, toluene and heptane) by 
thermocatalytic oxidation (with oxygen as oxidant) at concentrations ranging from $0.1 \mathrm{~g} . \mathrm{m}^{-3}$ to $2.0 \mathrm{~g} . \mathrm{m}^{-3}$ and temperatures between $100^{\circ} \mathrm{C}$ and $350^{\circ} \mathrm{C}$ (Lejeune et al., 2020b) was also proved to be efficient. Promising results were particularly obtained at quite low temperatures $\left(100^{\circ} \mathrm{C}-150^{\circ} \mathrm{C}\right)$ for ethanol removal, with complete mineralization in a moderate reactor length (Lejeune et al., 2020b). Considering these results, coupling ozonation and low temperatures $\left(<100^{\circ} \mathrm{C}\right)$ might be a good tradeoff for high process efficiency and is the topic of the present paper.

A detailed study about the removal of toluene in air by catalytic ozonation was carried out. The influence of the temperature, gas velocity and ozone inlet concentration was first experimentally assessed. The behavior of both toluene and ozone was analyzed (previous works focused on VOC removal in air by thermocatalytic oxidation without ozone, Lejeune et al., 2020b ; or ozone decomposition without any VOC, Lejeune et al., 2020a). With this dataset, a model was developed and adjusted to predict both ozone and toluene removal. Contrary to the empirical power-law kinetic model used for the thermocatalytic oxidation of VOCs with catalytic glass foam (Lejeune et al., 2020b), the model developed here is based on current knowledge about kinetics with heterogeneous catalysts and considered competitive adsorption of toluene and ozone on the catalyst surface with a first and second order reaction kinetics for ozone and toluene, respectively. The analysis of the model provided useful information about the catalytic ozonation and quantitative explanation of some experimental results. In the last part, the model was also used to predict the efficiency of the process under experimental conditions that are difficult to implement at the lab-scale in order to foresee the scale-up of the process and to optimize the catalytic reactor The predictive simulations permitted to carry out critical discussions about investment cost of the process, operating cost and performances, and finally efficient reactors were designed that can represent starting points for further works about industrial scale implementations.

\section{Material and methods}

\subsection{Synthesis of the catalytic glass foam}

The catalyst was synthesized according to recent works (Lejeune et al., 2020a; Lejeune et al., 2020b) aiming a mass loading of $0.1 \mathrm{wt} \%$ of active ruthenium nanoparticles which were supported on the glass foam (details are given in Supplementary materials part 1). Its 
structural characterization was detailed in a previous study (Lejeune et al., 2020a) and its thermal resistance up to $550^{\circ} \mathrm{C}$ was also showed (Lejeune et al., 2020b).

\subsection{Experimental setup for catalytic ozonation and analysis}

The experimental setup (Fig. 1) was already presented in a previous paper (Lejeune et al., 2020a) for ozone decomposition. The main difference comes from the presence of toluene in addition to ozone needing the presence of two $40 \mathrm{~L}$ Tedlar® bags, one with ozone in $\mathrm{O}_{2}$ and the second with the VOC in air, that were mixed before entrance in the process. The inlet

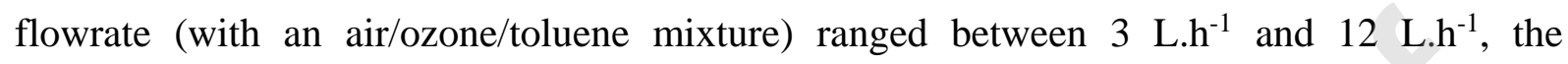
concentrations between $0.9 \mathrm{~g} . \mathrm{m}^{-3}$ and $1.2 \mathrm{~g} \cdot \mathrm{m}^{-3}$ for toluene, and $6.4 \mathrm{~g} . \mathrm{m}^{-3}$ and $11.2 \mathrm{~g} . \mathrm{m}^{-3}$ for ozone. A by-pass was used to quantify the initial ozone and toluene concentrations at steadystate. The catalyst diameter was $16 \mathrm{~mm}$ and its length varied between $25 \mathrm{~mm}$ and $63 \mathrm{~mm}$ depending on the sample. The reactor temperature ranged between $20^{\circ} \mathrm{C}$ and $90^{\circ} \mathrm{C}$. Some experiments were also performed with the same procedure but without VOC (ozone alone).

All experiments were carried out during at least 30 minutes to ensure steady-state conditions (no catalyst deactivation was observed with this duration). The pieces of catalytic glass foams were changed after around 3 hours of use to prevent from possible deactivation of the catalyst.

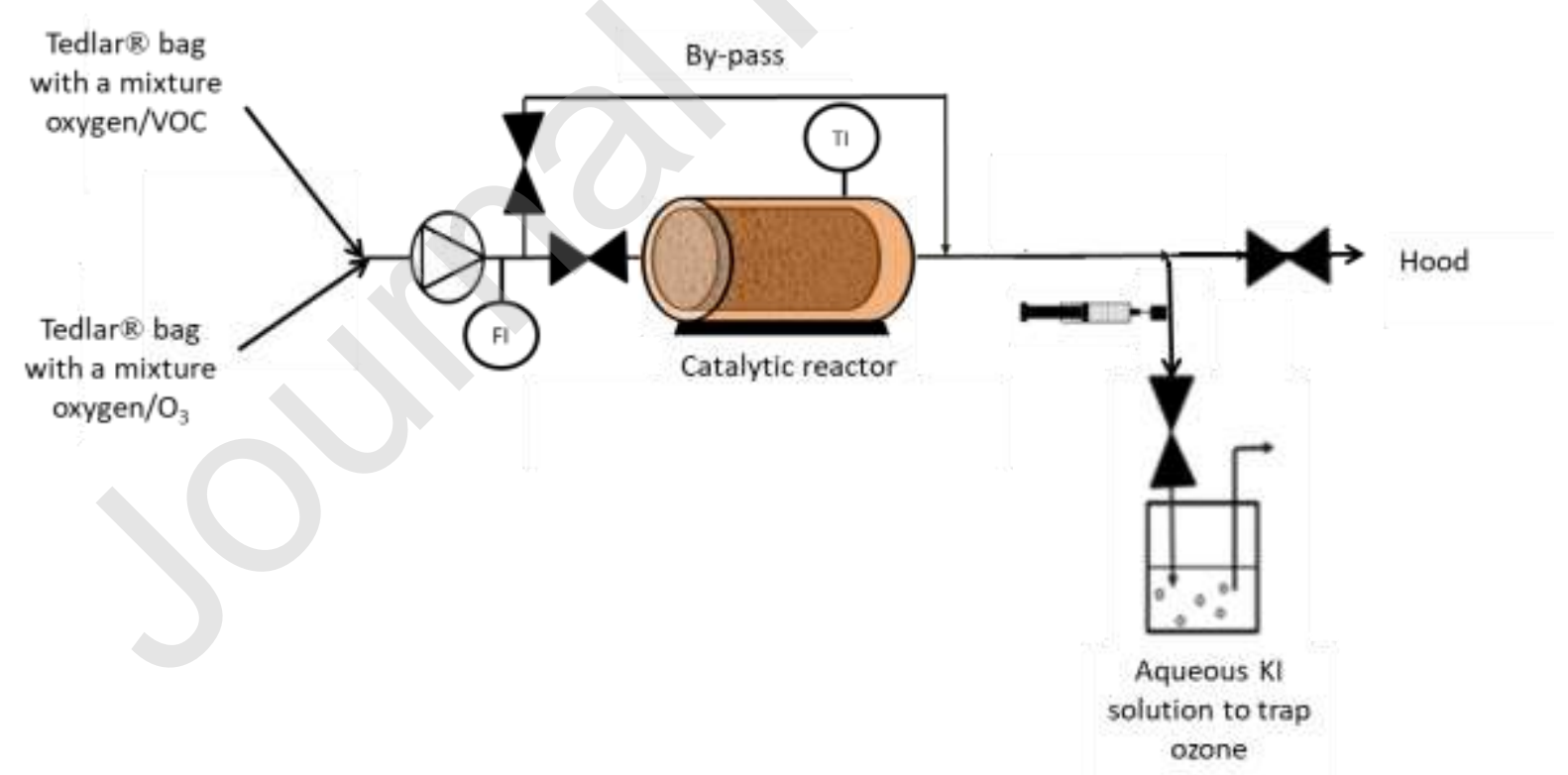

Fig. 1 - Layout of the setup for VOC removal by catalytic ozonation with a catalytic glass foam - TI: Temperature Indicator - FI: Flowrate Indicator 
Ozone was quantified with an iodometric method (Birdsall et al., 1952) and toluene was quantified by gas chromatography. The details of the analyzes can be found in

\section{Supplementary materials part 2.}

The removal efficiency (Eff, \%) and apparent experimental rate of reaction (r, g. $\left.\mathrm{m}^{-3} \cdot \mathrm{s}^{-1}\right)$ were calculated according to the inlet and outlet concentrations for both ozone and toluene (Eq. (1) to Eq. (4)).

$$
\begin{aligned}
& \mathrm{Eff}_{\mathrm{O}_{3}}=\frac{\left[\mathrm{O}_{3}\right]_{\text {inlet }}-\left[\mathrm{O}_{3}\right]_{\text {outlet }}}{\left[\mathrm{O}_{3}\right]_{\text {inlet }}} \times 100 \\
& \mathrm{r}_{\mathrm{O}_{3}}=\frac{\left[\mathrm{O}_{3}\right]_{\text {inlet }}-\left[\mathrm{O}_{3}\right]_{\text {outlet }}}{\tau}
\end{aligned}
$$

Eff $_{\text {Toluene }}=\frac{[\text { Toluene }]_{\text {inlet }}-[\text { Toluene }]_{\text {outlet }}}{[\text { Toluene }]_{\text {inlet }}} \times 100$

$\mathrm{r}_{\text {Toluene }}=\frac{[\text { Toluene }]_{\text {inlet }}-[\text { Toluene }]_{\text {outlet }}}{\tau}$

With $\left[\mathrm{O}_{3}\right]_{\text {inlet }}$ the ozone concentration at the inlet of the reactor $\left(\mathrm{g} \cdot \mathrm{m}^{-3}\right),\left[\mathrm{O}_{3}\right]_{\text {outlet }}$ the ozone concentration at the outlet of the reactor $\left(\mathrm{g}_{\mathrm{m}} \mathrm{m}^{-3}\right)$, [Toluene $]_{\text {inlet }}$ the toluene concentration at the inlet of the reactor $\left(\mathrm{g} \cdot \mathrm{m}^{-3}\right)$, [Toluene] $]_{\text {outlet }}$ the toluene concentration at the outlet of the reactor $\left(\mathrm{g} \cdot \mathrm{m}^{-3}\right)$ and $\tau$ the empty-tube residence time (s).

The Turn-Over Frequency (TOF, $\mathrm{h}^{-1}$ ) was determined with Eq. (5).

$\mathrm{TOF}=\frac{\dot{\mathrm{n}}_{\text {Toluene oxidized }}}{\mathrm{n}_{\mathrm{Ru}}}$

With $\dot{\mathrm{n}}_{\text {Toluene oxidized }}$ the number of moles of toluene oxidized per time unit calculated with Eq. (6) $\left(m o l . h^{-1}\right)$ and $n_{R u}$ the number of moles of ruthenium on the glass foam (mol) determined with Eq. (7) assuming that the ruthenium loading was 0.1 wt.\%.

$\dot{\mathrm{n}}_{\text {Toluene oxidized }}=\mathrm{F}_{\mathrm{v}} \times$ Eff $\times[\text { Toluene }]_{\text {inlet }}$

With $\mathrm{F}_{\mathrm{v}}$ the volumetric flowrate $\left(\mathrm{m}^{3} \cdot \mathrm{h}^{-1}\right)$.

$\mathrm{n}_{\mathrm{Ru}}=0.1 \mathrm{wt} . \% \times \frac{\mathrm{m}_{\text {foam }}}{\mathrm{MW}_{\mathrm{Ru}}}$

With $\mathrm{MW}_{\mathrm{Ru}}$ the molecular weight of $\mathrm{Ru}\left(\mathrm{g} \cdot \mathrm{mol}^{-1}\right)$ and $\mathrm{m}_{\text {foam }}$ the mass of the glass foam $(\mathrm{g})$.

\subsection{Modelling of the catalytic ozonation}




\subsubsection{Assumptions}

In order to optimize the removal of toluene with predictive simulations, the process was modeled according to the following assumptions. The process is isothermal and isobaric. Actually, the linear pressure drops were measured for this catalytic glass foam at room temperature (Lejeune et al., 2020a), and at a velocity of $0.01 \mathrm{~m} . \mathrm{s}^{-1}$ and $2.0 \mathrm{~m}$ of reactor length, the pressure drops are $6.2 \times 10^{3} \mathrm{~Pa}$ which can be neglected. This assumptions is confirmed here at room temperature and could be further checked at higher temperatures (up to $90^{\circ} \mathrm{C}$ ) if promising results are found with an increase in temperature.

The process works under steady-state flow and the catalytic glass foam is a plug-flow reactor meaning that axial dispersion is neglected. This assumption was demonstrated in solid foams packing with similar pore sizes (Stemmet et al., 2007; Ladi, 2016) and it is strengthened by the fact that the Peclet number relative to mass transfer is high $(\mathrm{Pe}>>1)$. Unidirectional flow inside the catalytic glass foam is assumed. The by-products, $\mathrm{CO}_{2}$ and $\mathrm{H}_{2} \mathrm{O}$ produced were not identified nor quantified as it was already done by Aghbolaghy et al. (2018) and it was assumed that they do not influence the kinetics of reaction. The internal mass transfer limitations were not considered taking into account that the support is macroporous (Lejeune et al., 2020a). Moreover, the catalyst wall thickness is very small (around $0.05 \mathrm{~mm}$ ) and the Thiele modulus is very low (small compared to one) which strengthens this assumption (Aguirre et al., 2020).

Finally, a Langmuir-Hinshelwood mechanism was considered as it often permits to accurately describe the kinetics of oxidation of VOCs with heterogeneous catalysts (Shahzad Kamal et al., 2016; Biard et al., 2007; Behar et al., 2015). For ozone, a competitive adsorption between ozone and toluene on the catalyst surface and a monomolecular reaction of $\mathrm{O}_{3}$ were considered. This assumption is supported by the fact that, at the temperatures involved in this study, VOCs are not degraded without ozone whereas ozone is degraded alone (Lejeune et al., 2020a). For toluene, a competitive adsorption and a bimolecular reaction (reactive oxygen species from ozone and toluene together) were considered. It means that the rate of reaction depends on the fraction of active sites occupied by both ozone and toluene. The reaction rate constants follow an Arrhenius law and the adsorption constants a Van't Hoff law (Behar et al., 2015). 
Other models without adsorption step were also tested (results not shown) but the agreement between those models and the experimental results were not good, that is why the bimolecular Langmuir-Hinshelwood mechanism was chosen.

\subsubsection{Equations of the model}

Based on the previously presented assumptions and considering that the kinetics of reaction can be described by a Langmuir-Hinshelwood mechanism, the behavior of toluene and ozone in the reactor was modelled with Eq. (8) to Eq. (15), in which $\mathrm{x}$ is the coordinate along the axis (Biard et al., 2007). Eqs. (8) and (9) refer to the gas phase and Eqs. (10) and (11) to the solid phase (surface of the catalyst).

$$
\begin{aligned}
& \mathrm{v} \times \frac{\mathrm{d}[\text { Toluene }]}{\mathrm{dx}}+\mathrm{k}_{\mathrm{m}, \text { Toluene }} \times \mathrm{a}_{\mathrm{v}} \times\left([\text { Toluene }]-[\text { Toluene }]_{\text {surface }}\right)=0 \\
& \mathrm{v} \times \frac{\mathrm{d}\left[\mathrm{O}_{3}\right]}{\mathrm{dx}}+\mathrm{k}_{\mathrm{m}, 03} \times \mathrm{a}_{\mathrm{v}} \times\left(\left[\mathrm{O}_{3}\right]-\left[\mathrm{O}_{3}\right]_{\text {surface }}\right)=0 \\
& \mathrm{k}_{\mathrm{m}, \text { Toluene }} \times \mathrm{a}_{\mathrm{v}} \times\left([\text { Toluene }]-[\text { Toluene }]_{\text {surface }}\right)=\frac{\mathrm{k}_{\text {Toluene }} \times \mathrm{K}_{\text {Toluene }} \times \mathrm{K}_{\mathrm{O} 3} \times[\text { Toluene }]_{\text {surface }} \times\left[\mathrm{O}_{3}\right]_{\text {surface }}}{\left(1+\mathrm{K}_{\text {Toluene }} \times[\text { Toluene }]_{\text {surface }}+\mathrm{K}_{\mathrm{O} 3} \times\left[\mathrm{O}_{3}\right]_{\text {surface }}\right)^{2}}
\end{aligned}
$$

$$
\begin{aligned}
& \mathrm{k}_{\mathrm{m}, \mathrm{O} 3} \times \mathrm{a}_{\mathrm{v}} \times\left(\left[\mathrm{O}_{3}\right]-\left[\mathrm{O}_{3}\right]_{\text {surface }}\right)=\frac{\mathrm{k}_{\mathrm{O} 3} \times \mathrm{K}_{\mathrm{O} 3} \times\left[\mathrm{O}_{3}\right]_{\text {surface }}}{\left(1+\mathrm{K}_{\text {Toluene }} \times[\text { Toluene }]_{\text {surface }}+\mathrm{K}_{\mathrm{O} 3} \times\left[\mathrm{O}_{3}\right]_{\text {surface }}\right)} \\
& \mathrm{k}_{\text {Toluene }}=\mathrm{A}_{\text {Toluene }} \times \exp \left(\frac{-\mathrm{E}_{\mathrm{a}, \text { Toluene }}}{\mathrm{R} \times \mathrm{T}}\right) \\
& \mathrm{K}_{\text {Toluene }}=\mathrm{K}_{0, \text { Toluene }} \times \exp \left(\frac{-\Delta \mathrm{H}_{\text {ads,Toluene }}}{\mathrm{R} \times \mathrm{T}}\right) \\
& \mathrm{k}_{\mathrm{O} 3}=\mathrm{A}_{\mathrm{O} 3} \times \exp \left(\frac{-\mathrm{E}_{\mathrm{a}, \mathrm{O} 3}}{\mathrm{R} \times \mathrm{T}}\right) \\
& \mathrm{K}_{\mathrm{O} 3}=\mathrm{K}_{0,03} \times \exp \left(\frac{-\Delta \mathrm{H}_{\mathrm{ads}, \mathrm{O} 3}}{\mathrm{R} \times \mathrm{T}}\right)
\end{aligned}
$$

With $\mathrm{v}$ the empty tube superficial gas velocity $\left(\mathrm{m} \cdot \mathrm{s}^{-1}\right)$, [Toluene] the toluene concentration in the gas phase $\left(\mathrm{mol} \cdot \mathrm{m}^{-3}\right), \mathrm{k}_{\mathrm{m}, \mathrm{i}}$ the mass transfer coefficient of species $\mathrm{i}$ ( $\mathrm{i}$ can be toluene or ozone) $\left(\mathrm{m} \cdot \mathrm{s}^{-1}\right), \mathrm{a}_{\mathrm{v}}$ the active specific surface area of the catalyst $\left(\mathrm{m}^{-1}\right)$, [Toluene] $]_{\text {surface }}$ the toluene concentration at the catalyst surface $\left(\mathrm{mol} \cdot \mathrm{m}^{-3}\right),\left[\mathrm{O}_{3}\right]$ the ozone concentration in the gas phase $\left(\mathrm{mol} \cdot \mathrm{m}^{-3}\right),\left[\mathrm{O}_{3}\right]_{\text {surface }}$ the ozone concentration at the catalyst surface $\left(\mathrm{mol} \cdot \mathrm{m}^{-3}\right), \mathrm{A}_{0, \mathrm{i}}$ the pre-exponential factor for the removal $\left(\mathrm{mol} \cdot \mathrm{m}^{-3} \cdot \mathrm{s}^{-1}\right), \mathrm{E}_{\mathrm{a}, \mathrm{i}}$ the activation energy for the removal 
$\left(\mathrm{J} \cdot \mathrm{mol}^{-1}\right)$, R the ideal gas constant $\left(\mathrm{J} \cdot \mathrm{mol}^{-1} \cdot \mathrm{K}^{-1}\right)$, T the temperature $(\mathrm{K}), \mathrm{K}_{0, \mathrm{i}}$ the pre-exponential factor for adsorption $\left(\mathrm{m}^{3} \cdot \mathrm{mol}^{-1}\right), \Delta \mathrm{H}_{\mathrm{ads}, \mathrm{i}}$ the enthalpy of adsorption $\left(\mathrm{J} \cdot \mathrm{mol}^{-1}\right)$.

In Eq. (8) to Eq. (11), the mass transfer was described with the term $\mathrm{k}_{\mathrm{m}, \mathrm{i}} \times \mathrm{a}_{\mathrm{v}}$. Several correlations which depend on the Reynolds and Schmidt numbers were already developed to calculate the mass transfer coefficient $\mathrm{k}_{\mathrm{m}, \mathrm{i}}$ in ceramic and metallic foams (Richardson et al., 2000; Groppi et al., 2007; Incera Garrido et al., 2008). In this study a laminar flow was experimentally assessed and Bracconi et al. (2018) suggested that for a purely laminar flow, the dependency of the mass transfer with the Reynolds number had an exponent of 0.33 and an exponent 0.33 is also commonly applied for the Schmidt number. Thus, the mass transfer coefficient $\mathrm{k}_{\mathrm{m}, \mathrm{i}}$ can be estimated according to Eq. (16).

$\mathrm{Sh}=\frac{\mathrm{k}_{\mathrm{m}, \mathrm{i}} \times \mathrm{d}_{\mathrm{p}}}{\mathrm{D}_{\mathrm{i}}}=\mathrm{A} \times \mathrm{Re}^{0.33} \times \mathrm{Sc}^{0.33}$

With Sh the Sherwood number (-), $d_{p}$ the mean pore diameter $(m), D_{i}$ the coefficient of diffusion of species $\mathrm{i}$ (ozone or toluene) in air $\left(\mathrm{m}^{2} \cdot \mathrm{s}^{-1}\right)$ and $\mathrm{A}$ a constant dealing with the mass transfer in the glass foam (-). Re and Sc are the Reynolds and Schmidt numbers (-) calculated with Eq. (17) and (18), respectively.

$\operatorname{Re}=\frac{\rho \times \mathrm{d}_{\mathrm{p}} \times \mathrm{v}}{\mu}$

With $\rho$ the density of air $\left(\mathrm{kg} \cdot \mathrm{m}^{-3}\right)$ and $\mu$ the viscosity of air (Pa.s).

$\mathrm{Sc}=\frac{\rho \times \mathrm{D}_{\mathrm{i}}}{\mu}$

Eq. (16) means that the mass transfer was not the same for ozone and toluene because their diffusion coefficients in air are not the same.

The density and viscosity of air were used for the calculations (the presence of ozone and toluene was not taken into account). The influence of the temperature was considered for the calculation of the density and viscosity of air (see equations in Supplementary Materials part 3), and for the calculation of the coefficients of diffusion of ozone (Massman, 1998) and toluene (Green and Perry, 2008) in air.

Finally, the active surface area $a_{v}$ was not experimentally determined and was incorporated in the model fitting parameter $\mathrm{A}^{\prime}\left(\mathrm{m}^{-1}\right)$ dealing with the possible mass transfer limitation. Hence the mass transfer efficiency was determined according to Eq. (19). 
$\mathrm{k}_{\mathrm{m}, \mathrm{i}} \times \mathrm{a}_{\mathrm{v}}=\frac{\mathrm{D}_{\mathrm{i}}}{\mathrm{d}_{\mathrm{p}}} \times \mathrm{A}^{\prime} \times \mathrm{Re}^{0.33} \times \mathrm{Sc}^{0.33}$

\subsubsection{Fitting of the parameters}

The parameters were fitted in two steps. First, the mass transfer parameter $\left(A^{\prime}\right)$ was adjusted according to the experimental data about ozone removal without toluene. To improve the accuracy of the model, other data (not shown) from another glass foam (with close porosity and pore diameter compared to the glass foam synthesized here) were also used. It makes a total of six data points dealing with gas velocities ranging from $0.0025 \mathrm{~m} . \mathrm{s}^{-1}$ to $0.017 \mathrm{~m} . \mathrm{s}^{-1}$. In a second step, the kinetic parameters for toluene and ozone oxidation were fitted according to the experimental results about removal of toluene in presence of ozone. Fourteen data points (seven for toluene and seven for ozone) were used to adjust the eight kinetic parameters (four for toluene and four for ozone).

\section{Results and discussion}

\subsection{Characterization of the catalyst}

The catalyst used in this work possessed an open porosity of $88 \%$ and a mean pore diameter of $0.33 \mathrm{~mm}$. The apparent density of the glass foam was $0.27 \mathrm{~g} . \mathrm{cm}^{-3}$. This open porosity is among the highest for glass foams (Lejeune et al., 2020a) but the mean pore diameter is quite low (it can reach almost $1 \mathrm{~mm}$ ) meaning that on the one hand, the pressure drops are higher than for the catalysts with larger pores but on the other hand, the compressive strength is high ensuring the mechanical resistance of the synthesized material (Lejeune et al., 2020a). The surface area of the glass foam was estimated around $1,000 \mathrm{~m}^{2} . \mathrm{m}^{-3}$ according to the model of Bracconi et al. (2018). Fig. 2 shows a photo, a SEM picture and a TEM picture of the Rudoped catalyst. The porous structure is clearly visible and each black dot on the TEM picture is a ruthenium nanoparticle impregnated on the support. Other TEM pictures are provided in the Supplementary materials part 4 to illustrate that $\mathrm{Ru}$ nanoparticles are deposited in the whole catalyst volume. 
a)

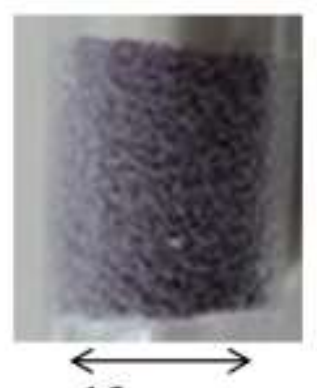

$16 \mathrm{~mm}$ b)

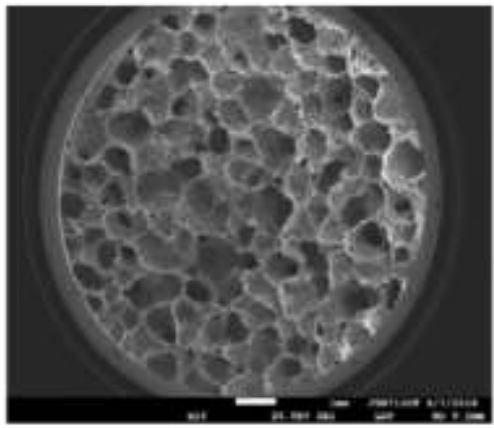

c)

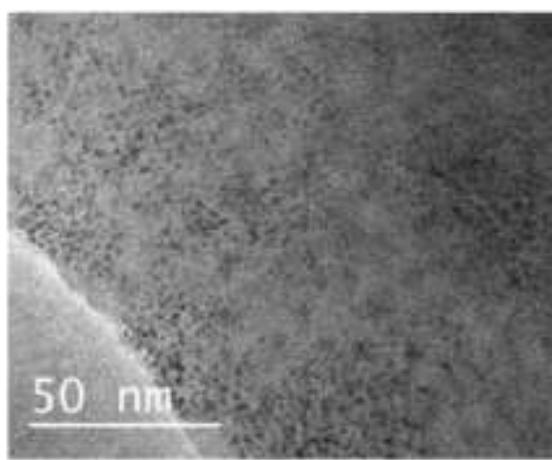

Fig. 2 - (a) Real picture of the glass foam support - (b) SEM picture of the glass foam support (scale bar $=1 \mathrm{~mm}$ ) - (c) TEM picture of the support impregnated with ruthenium nanoparticles

\subsection{Performances of the catalytic glass foam for ozonation}

The performances of the catalytic glass foam for the decomposition of ozone alone and for the removal of toluene in the presence of ozone are described in Table $\mathbf{1}$ in terms of removal efficiencies, rates of reaction and TOF (Eq. (1) to Eq. (5)) for both toluene and ozone. Some data are also given in Supplementary materials part 5 about the performances with other VOCs (acetone and ethanol) in order to highlight that the catalyst is efficient with different types of VOCs.

Table 1 - Performances of the catalytic glass foam for the removal of single ozone and toluene by catalytic ozonation

\begin{tabular}{|c|c|c|c|c|c|c|c|c|c|c|c|c|}
\hline \multirow[t]{2}{*}{ VOC } & \multirow{2}{*}{$\begin{array}{l}{[\text { VOC }]_{\text {inlet }}} \\
\left(\mathrm{g} \cdot \mathrm{m}^{-3}\right)\end{array}$} & \multirow{2}{*}{$\begin{array}{l}{\left[\mathrm{O}_{3}\right]_{\text {inlet }}} \\
\left(\mathrm{g} \cdot \mathrm{m}^{-3}\right)\end{array}$} & \multirow{2}{*}{$\begin{array}{l}\mathrm{v} \\
\left(\mathrm{m} . \mathrm{s}^{-1}\right)\end{array}$} & \multirow[t]{2}{*}{$\tau(s)$} & \multirow{2}{*}{$\begin{array}{l}\text { GHSV } \\
*\left(\mathrm{~h}^{-1}\right)\end{array}$} & \multirow{2}{*}{$\begin{array}{l}\mathrm{T} \\
\left({ }^{\circ} \mathrm{C}\right)\end{array}$} & \multicolumn{2}{|c|}{$\mathrm{r}\left(\mathrm{g} \cdot \mathrm{m}^{-3} \cdot \mathrm{s}^{-1}\right)$} & \multicolumn{2}{|c|}{ TOF $\left(h^{-1}\right)$} & \multicolumn{2}{|c|}{ Eff $(\%)$} \\
\hline & & & & & & & VOC & $\mathrm{O}_{3}$ & VOC & $\mathrm{O}_{3}$ & VOC & $\mathrm{O}_{3}$ \\
\hline- & - & 9.6 & 0.0025 & 18.2 & 198 & 20 & - & 0.25 & - & 5.9 & - & 47 \\
\hline - & - & 7.7 & 0.0042 & 10.7 & 336 & 20 & - & 0.37 & - & 8.8 & - & 52 \\
\hline- & - & 9.8 & 0.011 & 4.0 & 900 & 20 & - & 0.66 & - & 15.6 & - & 27 \\
\hline Toluene & 1.2 & 6.4 & 0.011 & 2.1 & 1714 & 30 & 0.052 & 0.38 & 0.6 & 7.1 & 10 & 13 \\
\hline & 1.0 & 8.4 & & 2.4 & 1500 & & 0.067 & 0.42 & 0.8 & 7.8 & 16 & 12 \\
\hline & 1.2 & 6.4 & & 2.1 & 1714 & 60 & 0.095 & 0.62 & 1.1 & 11.5 & 17 & 20 \\
\hline & 0.91 & 11.0 & & 3.1 & 1161 & & 0.094 & 1.01 & 1.1 & 18.7 & 32 & 28 \\
\hline & 1.2 & 6.4 & & 3.3 & 1091 & 90 & 0.092 & 1.38 & 1.1 & 25.6 & 26 & 70 \\
\hline & 1.2 & 9.7 & & 3.3 & 1091 & & 0.12 & 2.08 & 1.4 & 28.7 & 33 & 70 \\
\hline & 0.93 & 11.2 & & 2.1 & 1714 & & 0.21 & 2.13 & 2.4 & 39.6 & 47 & 40 \\
\hline
\end{tabular}

*GHSV: Gas Hourly Space Velocity $=\mathrm{F}_{\mathrm{V}} / \mathrm{V}_{\text {catalyst }}$, with $\mathrm{V}_{\text {catalyst }}$ the volume of the catalyst $\left(\mathrm{m}^{3}\right)$

3.2.1. Removal of ozone alone 
Ozone alone was removed at various gas velocities ranging from $0.0025 \mathrm{~m} . \mathrm{s}^{-1}$ to $0.011 \mathrm{~m} . \mathrm{s}^{-1}$ and inlet concentration around 9 g.m $\mathrm{m}^{-3}$ (Table 1). The higher the gas velocity, the higher the rate of ozone decomposition. This result suggests that the performances may be limited by the mass transfer in this range of operating conditions, as already highlighted in other studies about catalytic glass foams (Lejeune et al., 2020a; Lejeune et al., 2020b), and will be quantitatively detailed with the model (see next part). The influence of the mass transfer needs nevertheless to be considered with caution because the comparison of the rates of reaction is done with experiments at highly different residence times (between 4.0 seconds to 18.2 seconds).

The TOF for ozone also increases with the gas velocity and reaches $15.6 \mathrm{~h}^{-1}$ at the most. Compared with other applications for ozone decomposition in air, the rate of decomposition and TOF are in the same range of values as the results given by Jia et al. (2016) with manganese catalysts, highlighting the good activity of the ruthenium-doped glass foam. Several points needs nevertheless to be considered to qualify the comparison: on the one hand, ruthenium is more expensive than manganese but on the other hand the ruthenium loading is very low in this study ( $0.1 \mathrm{wt} . \%$ of Ru only). A cost analysis taking into account the cost of the overall catalyst (support and active metal particles) and catalyst lifetime would be necessary to compare several possible solutions but it is out of the scope of the study.

Finally, the conversion of ozone increases from $47 \%$ to $52 \%$ when the gas velocity goes from $0.0025 \mathrm{~m} . \mathrm{s}^{-1}$ to $0.0042 \mathrm{~m} . \mathrm{s}^{-1}$, and decreases to $27 \%$ at $0.011 \mathrm{~m} . \mathrm{s}^{-1}$ since the improvement in mass transfer did not compensate the decrease in residence time (only 4.0 seconds).

\subsubsection{Removal of toluene}

The removal of toluene in air and in presence of ozone was successfully performed at a gas velocity of $0.011 \mathrm{~m} . \mathrm{s}^{-1}$, thus proving the efficiency of the catalytic ruthenium-doped glass foam for ozonation (Table 1). The rates of oxidation and the associated TOFs for toluene were always around 10 times lower than for ozone because ozone was much more concentrated than toluene ( 5 to 10 times more). This result can also be attributed to a higher ozone reaction rate or to a better adsorption of ozone on the catalyst surface. These explanations will be quantitatively detailed owing to the model (see next part).

From a general point of view, the higher the temperature, the higher the reaction rate and TOF of both ozone decomposition and toluene oxidation, which shows the positive effect of the 
temperature on the process efficiency even if an adsorption step is involved. The effect of the temperature on both kinetic and adsorption constants is considered in the model.

More precisely, at $30^{\circ} \mathrm{C}$, the rates of toluene and ozone removal increase with an increase in the ozone inlet concentration from $6.4 \mathrm{~g} \cdot \mathrm{m}^{-3}$ to $8.4 \mathrm{~g} \cdot \mathrm{m}^{-3}$. At $60^{\circ} \mathrm{C}$, the rate of toluene oxidation is almost constant whatsoever the ozone inlet concentration while the rate of ozone decomposition increases between ozone concentration from $6.4 \mathrm{~g} . \mathrm{m}^{-3}$ to $11.0 \mathrm{~g} . \mathrm{m}^{-3}$. Actually, even if more ozone promotes the ozonation of toluene owing to a higher rate of formation of oxygen reactive species at the catalyst surface, too much ozone can also prevent toluene from reaching the catalyst active surface (competition between the two species is taken into account with the model). Finally, at $90^{\circ} \mathrm{C}$, the rate and TOF of toluene oxidation reach the highest recorded values. With the best tested operating conditions $\left(90^{\circ} \mathrm{C}\right.$ and $11.2 \mathrm{~g} . \mathrm{m}^{-3}$ inlet ozone concentration), the TOF is $2.4 \mathrm{~h}^{-1}$ for toluene and $39.6 \mathrm{~h}^{-1}$ for ozone and the removal efficiency of toluene goes up to $47 \%$.

The rate of oxidation of toluene is of the same order of magnitude as other literature data. Actually, in a previous study about the use of the same type of catalytic glass foam for the removal of toluene by thermocatalytic oxidation (Lejeune et al., 2020b), the rate of oxidation reaches $0.12 \mathrm{~g} \cdot \mathrm{m}^{-3} \cdot \mathrm{s}^{-1}$ at $250^{\circ} \mathrm{C}$ and $1.0 \mathrm{~g} \cdot \mathrm{m}^{-3}$ inlet toluene concentration. $\mathrm{Hu}$ et al. (2017) obtained a rate of toluene ozonation between 0.03 and $0.10 \mathrm{~g} \cdot \mathrm{m}^{-3} \cdot \mathrm{s}^{-1}$ with a $\mathrm{MnO}_{2} /$ graphene catalyst at temperatures ranging from $22^{\circ} \mathrm{C}$ and $60^{\circ} \mathrm{C}$. As previously highlighted, this comparison needs to be considered with caution because ruthenium is known to be more efficient than $\mathrm{MnO}_{2}$, but these results strengthen than the catalytic glass foam developed in this study can be competitive.

\subsection{Modelling of the catalytic ozonation of toluene}

According to the model previously presented and the data given in Table $\mathbf{1}$, an accurate model of the oxidation of toluene by catalytic ozonation was adjusted.

3.3.1. Fitting of the mass transfer coefficient according to ozone decomposition with single ozone

First, the mass transfer limitation was studied with the experiments about ozone decomposition without toluene. The model fitted quite well with the experimental data $(12 \%$ of average relative error on the outlet concentrations). The mass transfer parameter is: $A^{\prime}=30.7$ $\mathrm{m}^{-1}$. The volumetric mass transfer coefficient $\left(\mathrm{k}_{\mathrm{v}, \mathrm{i}}=\mathrm{k}_{\mathrm{m}, \mathrm{i}} \times \mathrm{a}_{\mathrm{v}}\right)$ at $20^{\circ} \mathrm{C}$ and $0.01 \mathrm{~m} \cdot \mathrm{s}^{-1}$ is 0.84 
$\mathrm{s}^{-1}$ for ozone (it is $0.55 \mathrm{~s}^{-1}$ for toluene according to its diffusion coefficient at $20^{\circ} \mathrm{C}$ ). These values are lower compared to some literature data gathered with ceramic or metallic foams (Groppi et al., 2007; Incera Garrido et al., 2008) but the gas velocity used here was low compared to other works.

The kinetic and adsorption constants dealing with the kinetic of decomposition of ozone at $20^{\circ} \mathrm{C}$ according to the Langmuir-Hinshelwood mechanism are $\mathrm{k}_{\mathrm{O} 3}=0.017 \mathrm{~mol} \cdot \mathrm{m}^{-3} \cdot \mathrm{s}^{-1}$ and $\mathrm{K}_{\mathrm{O} 3}=3.81 \mathrm{~m}^{3} \cdot \mathrm{mol}^{-1}$.

3.3.2. Fitting of the oxidation kinetic parameters according to toluene and ozone removals

For the removal of toluene in the presence of ozone, the model and the experiments were in good agreement with $7 \%$ of average relative error whatsoever for ozone and toluene outlet concentrations (the corresponding parity diagrams are provided in Supplementary materials part 6). The fitted parameters are given in Table 2.

Table 2 - Fitted kinetic parameters dealing with the Langmuir-Hinshelwood mechanism for the removal of toluene by catalytic ozonation

\begin{tabular}{llll}
\hline Type of parameter & Parameter & Value & Unit \\
\hline Kinetic of ozone decomposition & $\mathrm{A}_{\mathrm{O} 3}$ & $2.5 \times 10^{6}$ & $\mathrm{~mol} \cdot \mathrm{m}^{-3} \cdot \mathrm{s}^{-1}$ \\
& $\mathrm{E}_{\mathrm{a}, \mathrm{O} 3}$ & 46 & $\mathrm{~kJ} \cdot \mathrm{mol}^{-1}$ \\
& $\mathrm{~K}_{0, \mathrm{O} 3}$ & 0.0045 & $\mathrm{~m}^{3} \cdot \mathrm{mol}^{-1}$ \\
Kinetic of toluene oxidation & $\Delta \mathrm{H}_{\mathrm{ads}, \mathrm{COV}}$ & -16 & $\mathrm{~kJ} \cdot \mathrm{mol}^{-1}$ \\
& $\mathrm{~A}_{\text {toluene }}$ & $1.9 \times 10^{8}$ & $\mathrm{~mol} \cdot \mathrm{m}^{-3} \cdot \mathrm{s}^{-1}$ \\
& $\mathrm{E}_{\mathrm{a} \text {,toluene }}$ & 61 & $\mathrm{~kJ} \cdot \mathrm{mol}^{-1}$ \\
& $\mathrm{~K}_{0, \text { toluene }}$ & 0.0062 & $\mathrm{~m}^{3} \cdot \mathrm{mol}^{-1}$ \\
& $\Delta \mathrm{H}_{\text {ads,toluene }}$ & -22 & $\mathrm{~kJ} \cdot \mathrm{mol}^{-1}$ \\
\hline
\end{tabular}

The activation energy $\left(61 \mathrm{~kJ} \cdot \mathrm{mol}^{-1}\right)$ for toluene oxidation is in good agreement with available literature data in catalytic ozonation $\left(44 \mathrm{~kJ} \mathrm{~mol}^{-1}\right.$ (Rezaei et al., 2013) and $48 \mathrm{~kJ} \cdot \mathrm{mol}^{-1}$ (Hu et al., 2017)). Behar et al. (2015) reviewed the activation energy for toluene oxidation in thermocatalytic oxidation. The values (more than 20 data) ranged between $42 \mathrm{~kJ} \cdot \mathrm{mol}^{-1}$ and $165 \mathrm{~kJ} \cdot \mathrm{mol}^{-1}$ which are also consistent with the value fitted in this work.

About the adsorption, the toluene adsorption enthalpy is highly negative and quite close to most of the literature data (ranging between $-58 \mathrm{~kJ} \cdot \mathrm{mol}^{-1}$ (Hu et al., 2017) to $-26 \mathrm{~kJ} \mathrm{~mol}^{-1}$ (Hu, 2011), except one value of $-271 \mathrm{~kJ}^{-\mathrm{mol}^{-1}}$ (Bedia et al., 2010)). It is also possible to determine the toluene adsorption entropy $\left(\Delta \mathrm{S}_{\text {toluene }}\right)$ according to Eq. (20) (Hu et al., 2017). It is -42.9 $\mathrm{J} . \mathrm{mol}^{-1} \cdot \mathrm{K}^{-1}$, which respects the thermodynamic constraints given by Hu et al. (2017). Actually, 
the loss of entropy in the adsorption of toluene onto the catalyst surface is higher than 41.9 $\mathrm{J} . \mathrm{mol}^{-1} \cdot \mathrm{K}^{-1}$ but lower than the standard gas entropy of toluene $\left(320.7 \mathrm{~J} \cdot \mathrm{mol}^{-1} \cdot \mathrm{K}^{-1}\right.$ (Bedia et al., 2010)). It suggested that a proper kinetic model was selected.

$$
\ln \left(\mathrm{K}_{0, \text { toluene }}\right)=\frac{\Delta \mathrm{S}_{\text {toluene }}}{\mathrm{R}}
$$

The constant of adsorption of ozone $\mathrm{K}_{\mathrm{O} 3}$ calculated with Eq. (15) at $20^{\circ} \mathrm{C}$ is $3.79 \mathrm{~m}^{3} \cdot \mathrm{mol}^{-1}$, which is close to the parameter fitted with single ozone $\left(3.81 \mathrm{~m}^{3} \cdot \mathrm{mol}^{-1}\right)$. The ozone reaction rate constant $\mathrm{k}_{\mathrm{O} 3}$, calculated with Eq. (14) at $20^{\circ} \mathrm{C}$, is $0.016 \mathrm{~mol} \cdot \mathrm{m}^{-3} \cdot \mathrm{s}^{-1}$ which is also very close to the data determined with ozone alone $\left(0.017 \mathrm{~mol} . \mathrm{m}^{-3} \cdot \mathrm{s}^{-1}\right)$. These results tend to validate the model fitted with the experiments with toluene and ozone.

\subsubsection{Quantitative explanation of some experimental results with the model}

In order to explain some experimental results, the rates of reaction for ozone decomposition $\left(\mathrm{V}_{\text {O3 }}\right)$ and toluene removal $\left(\mathrm{V}_{\text {VOC }}\right)$ were calculated at $30^{\circ} \mathrm{C}$ and $90^{\circ} \mathrm{C}$ depending on ozone concentration. The ratios between the concentration at the catalyst surface and in the air were also estimated (Fig. 3). The calculations were performed for different ratios of ozone to VOC concentration, namely 17/3 which is the stoichiometric ratio between ozone and toluene, a tenth of the stoichiometric ratio and 10 times the stoichiometric ratio. On Fig. 3, the rates of reaction were divided by a reference reaction rate ( $\mathrm{V}_{\mathrm{O} 3 \text {,ref }}$ and $\left.\mathrm{V}_{\mathrm{VOC}, \mathrm{ref}}\right)$ calculated for $0.1 \mathrm{~g} . \mathrm{m}^{-3}$ of ozone concentration and the stoichiometric ratio between ozone and toluene. Several conclusions can be drawn from these data.

(i) For low ozone concentrations, the rate of ozone decomposition is proportional to the ozone concentration, and the rate of toluene oxidation is proportional to both ozone and toluene concentrations. It means that the kinetic follows a first order for ozone and a second order for toluene. For higher ozone concentrations, the rates of ozone and toluene removal start to deflect meaning that the terms $\mathrm{K}_{\text {Toluene }} \times[\text { Toluene }]_{\text {surface }}$ and $\mathrm{K}_{\mathrm{O} 3} \times\left[\mathrm{O}_{3}\right]_{\text {surface }}$ become significant (compared to 1 in the denominator of Eqs. (10) and (11)), and so the competitive effects for the adsorption also become significant and the catalyst starts to be saturated.

(ii) The mass transfer limitation is quite low, especially at $30^{\circ} \mathrm{C}$ where it is also almost null. At $90^{\circ} \mathrm{C}$, its impact is higher (the ratio between the surface concentration and the bulk concentration goes down to around $65 \%$ ) and can be due to the fact that the ozone and toluene reaction rates increase more with the temperature than the mass-transfer rates. These results highlight that playing on the gas velocity may not be an efficient solution to improve the 
process efficiency. It can also be noticed that for toluene, there is a minimum of the surface to bulk concentration ratio.

(iii) Whatsoever the concentrations, the temperature and the ozone to toluene ratio, the rate of ozone decomposition is clearly higher than the rate of toluene oxidation (between 40 and 6,000 times more, the values are given in Supplementary materials part 7). It means that increasing the ozone concentration would be the best solution to improve toluene removal, but the drawback could be the remaining ozone at the outlet of the process that needs to be removed by a post-treatment.

(iv) As previously highlighted, increasing the temperature also increases the rates of reaction between 5 to 30 times for ozone and 3 to 60 times for toluene between $30^{\circ} \mathrm{C}$ and $90^{\circ} \mathrm{C}$. This improvement is quite limited compared to the effect of the ozone concentration, and it comes from the fact that increasing the temperature increases the rate of decomposition but decreases the adsorption.

(v) Finally, for the lowest ozone to toluene ratio (so when there is more toluene than ozone), the rate of toluene oxidation becomes lower than the rate of toluene oxidation for higher ozone to toluene ratio, showing that there are competitive effects in disfavor of toluene. 
a) Ozone at $30^{\circ} \mathrm{C}$

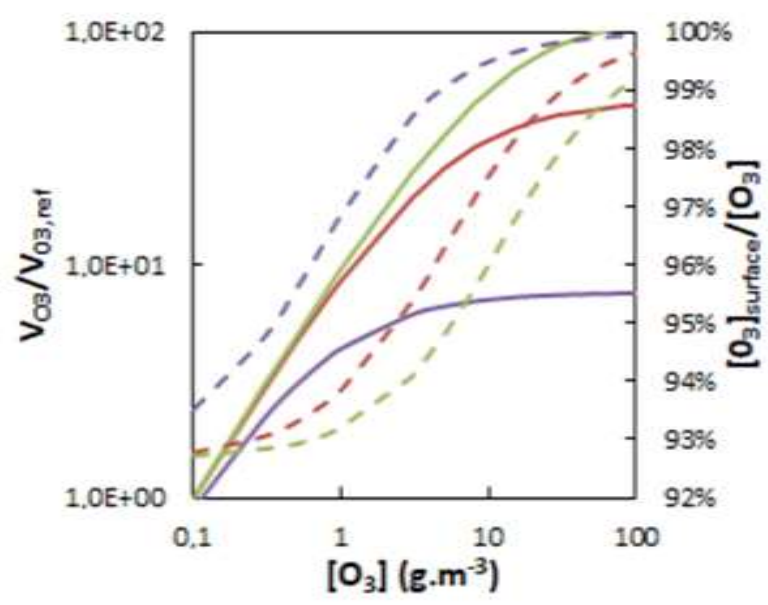

c) Ozone at $90^{\circ} \mathrm{C}$
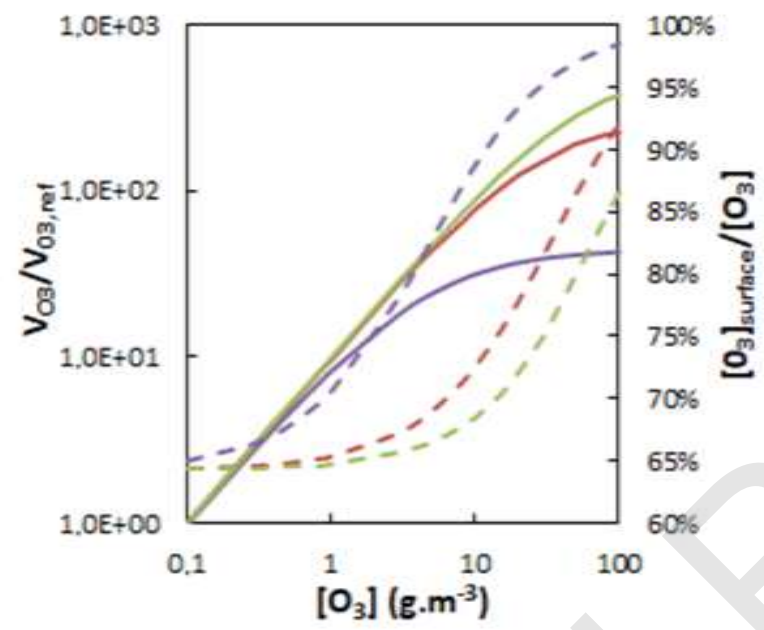

b) Toluene at $30^{\circ} \mathrm{C}$

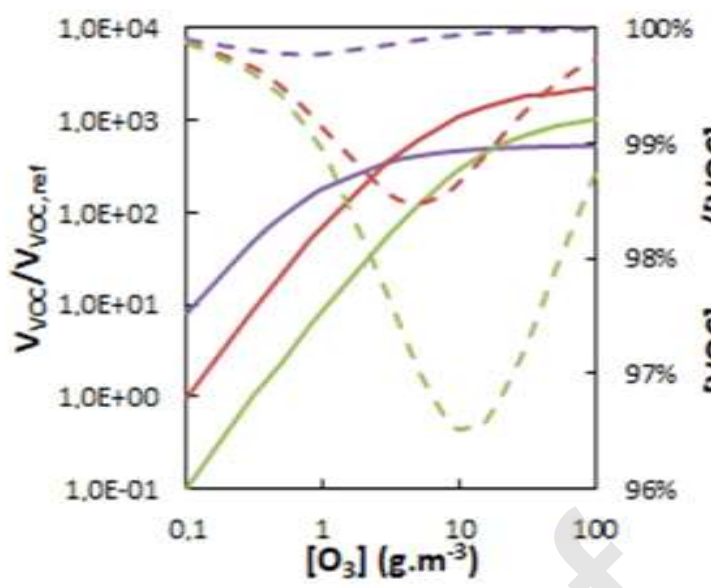

d) Toluene at $90^{\circ} \mathrm{C}$

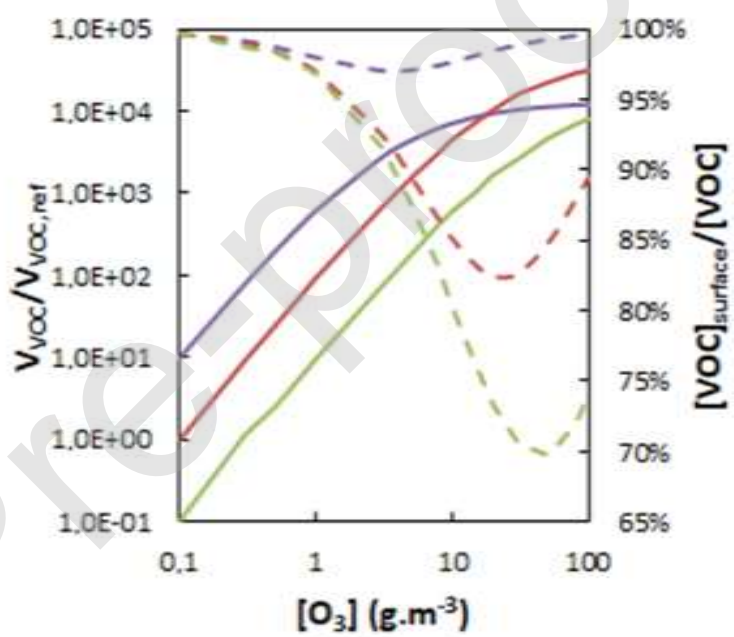

Fig. 3 - Ratio between the rate of reaction $V_{03}$ and the reference rate of reaction $V_{03 \text {,ref }}$ (full lines, -) ; and ratio of the surface to bulk concentration (dashed lines, - - -) in function of the ozone concentration

red: stoichiometric ratio between ozone and toluene (17/3) - green: 10 times the stoichiometric ratio - purple: a tenth of the stoichiometric ratio

\subsection{Predictive simulations to optimize toluene abatement}

\subsubsection{Scope of the simulations and preliminary analysis}

With the above presented model, the removal of toluene by catalytic ozonation was optimized playing on the gas velocity, temperature, ozone inlet concentration, and design of the reactor. In order to compare the results, three criteria were taken into account: (i) the performances of the process for toluene abatement, (ii) the energy consumption or OPEX (heating, ozone generation) and (iii) the investment cost related to the reactor CAPEX (according to its length). These criteria were quantitatively compared but a cost analysis was not performed 
because it is out of the scope of the work. All simulations were performed with the same toluene inlet concentration $\left(1.0 \mathrm{~g} \cdot \mathrm{m}^{-3}\right)$.

Fig. 4 presents the profiles of concentrations of ozone and toluene for a reference simulation close to the experimental conditions $\left(30^{\circ} \mathrm{C}, 0.010 \mathrm{~m} . \mathrm{s}^{-1}\right.$ and $10.0 \mathrm{~g} \cdot \mathrm{m}^{-3}$ inlet ozone concentration). There is a fast decrease in concentration of both compounds at the beginning of the reactor due to the high concentrations that enhance the rates of reaction and adsorption. After around one third of the reactor, the variations of toluene concentration become quite slow and almost null from the middle of the reactor. This behavior comes from the low ozone concentration involved in the second half of the reactor, which lowers the rate of toluene oxidation.

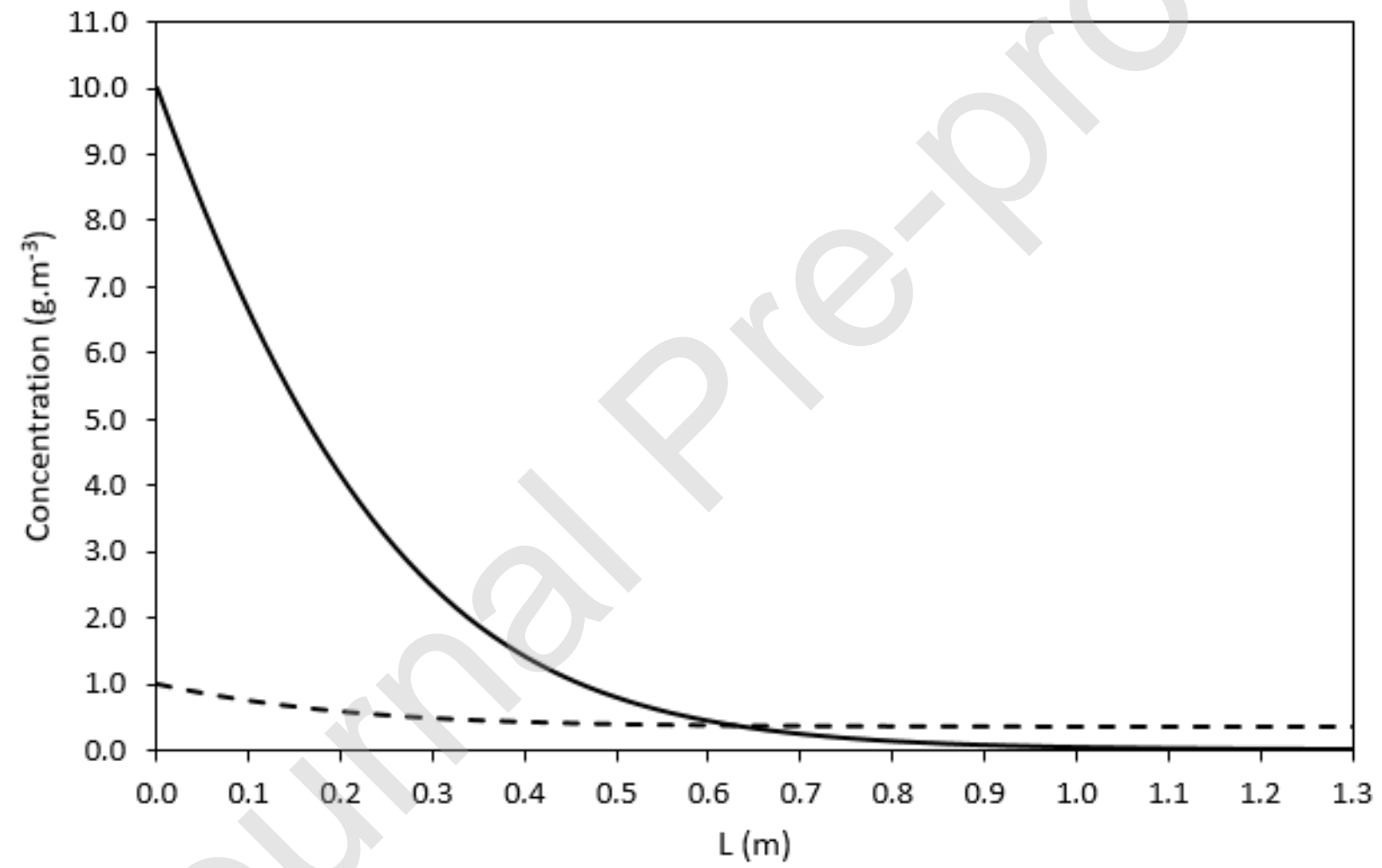

Fig. 4 - Concentration profiles for the simulation with $\mathrm{T}=30^{\circ} \mathrm{C}, \mathrm{v}=\mathbf{0 . 0 1 0} \mathrm{m} . \mathrm{s}^{-1}$, $\left[\mathrm{O}_{3}\right]_{\text {inlet }}=10.0 \mathrm{~g} \cdot \mathrm{m}^{-3}$ and $[\text { Toluene }]_{\text {inlet }}=1.0 \mathrm{~g} \cdot \mathrm{m}^{-3}-$ full line (-): ozone - dashed line (- - -): toluene

According to these results, different aims were considered for the simulations. First, a constraint about the removal of ozone was imposed, varying the operating conditions. The length of the reactor was adjusted to fulfill this constraint and the removal of toluene was also analyzed. The results with two different constraints about ozone were compared: (i) full ozone 
removal (>99.9) and (ii) removal of ozone until its concentration almost does not change anymore, that is to say, until the ozone concentration went down to $0.5 \mathrm{~g} . \mathrm{m}^{-3}$. In this second case, an ozone destructor would be necessary at the outlet of the process to eliminate the remaining ozone. Second, a constraint about toluene removal was imposed. A value of $88 \%$ of removal was chosen $\left(120 \mathrm{mg} \cdot \mathrm{m}^{-3}\right.$ of toluene outlet concentration) in order to match with French regulation about the VOCs' emissions.

All the results of the simulations are summarized in Table 3. In this table, the values in italics deal with the imposed constraints (ozone or toluene removal).

Table 3 - Results of the predictive simulations for toluene removal by catalytic ozonation

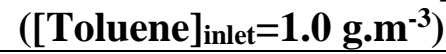

\begin{tabular}{llllllll}
\hline $\mathrm{T}\left({ }^{\circ} \mathrm{C}\right)$ & $\mathrm{v}\left(\mathrm{m} \cdot \mathrm{s}^{-1}\right)$ & {$\left[\mathrm{O}_{3}\right]_{\text {inlet }}\left(\mathrm{g} \cdot \mathrm{m}^{-3}\right)$} & $\mathrm{L}(\mathrm{m})$ & $\tau(\mathrm{s})$ & {$\left[\mathrm{O}_{3}\right]_{\text {outlet }}\left(\mathrm{g} \cdot \mathrm{m}^{-3}\right)$} & $\mathrm{Eff}_{\mathrm{O} 3}(\%)$ & $\mathrm{Eff}_{\text {toluene }}(\%)$ \\
\hline 30 & 0.010 & 10 & 1.3 & 130 & $<0.01$ & $>99.9$ & 64.2 \\
& & & 0.58 & 58 & 0.5 & 95.0 & 61.7 \\
60 & 0.010 & 10 & 0.45 & 45 & $<0.01$ & $>99.9$ & 59.4 \\
& & & 0.19 & 19 & 0.5 & 95.0 & 57.1 \\
90 & 0.010 & \multirow{2}{*}{10} & 0.21 & 21 & $<0.01$ & $>99.9$ & 52.6 \\
& & & 0.09 & 9 & 0.5 & 95.0 & 50.5 \\
90 & 0.030 & \multirow{2}{*}{10} & 0.58 & 19 & $<0.01$ & $>99.9$ & 53.7 \\
& & & 0.24 & 8 & 0.5 & 95.0 & 51.6 \\
90 & 0.100 & \multirow{2}{*}{10} & 1.8 & 18 & $<0.01$ & $>99.9$ & 54.8 \\
& & & 0.73 & 7.3 & 0.5 & 95.0 & 52.6 \\
90 & 0.010 & 20 & 0.22 & 22 & $<0.01$ & $>99.9$ & 72.3 \\
& & & 0.11 & 11 & 0.5 & 97.5 & 71.1 \\
90 & 0.010 & 30 & 0.21 & 21 & $<0.01$ & $>99.9$ & 81.9 \\
& & & 0.12 & 12 & 0.5 & 98.3 & 81.1 \\
90 & 0.010 & 42 & 0.21 & 21 & $<0.01$ & $>99.9$ & 88.0 \\
& & 46 & 0.11 & 11 & 1.3 & 97.1 & 88.0 \\
\hline
\end{tabular}

In Italics: constraint imposed for the simulation

3.4.2. Potential of the catalytic reactor : influence of the operating conditions

The potential of the catalytic reactor was assessed according to the simulations with constraints about ozone removal. Increasing the temperature implies opposite effects on the process performances and cost. From the performances point of view, the higher the temperature, the lower the removal of toluene because the decomposition of ozone is so fast that most of the reactor is operated with a low ozone concentration hence a low toluene oxidation rate. About the cost of the process, heating obviously requires an extra cost, but the length of the reactor is lower at high temperature. To reach full ozone abatement, the reactor's length is six times lower at $90^{\circ} \mathrm{C}$ than at $30^{\circ} \mathrm{C}(0.21 \mathrm{~m}$ against $1.3 \mathrm{~m})$ leading to lower 
CAPEX. Taking into account all these criteria and according to the high gain in reactor length at high temperature, the next simulations were performed at $90^{\circ} \mathrm{C}$.

The gas velocity was then increased from $0.010 \mathrm{~m} \cdot \mathrm{s}^{-1}$ to $0.10 \mathrm{~m} \cdot \mathrm{s}^{-1}$. Even if the maximum gas velocity is out of the experimental conditions tested, the model was used here to simulate operating conditions that were not possible to try in the laboratory. The high reactor length needed at $0.10 \mathrm{~m} \cdot \mathrm{s}^{-1}$ increases the CAPEX of the process (and also the OPEX due to higher pressure drops, even if they remain quite limited at these gas velocities (Lejeune et al., 2020a)). The removal of toluene was almost constant in the range of gas velocities tested (52$55 \%$ for full ozone removal and 51-53\% for the second set of simulations $\left(0.5 \mathrm{~g} \cdot \mathrm{m}^{-3}\right.$ of ozone outlet concentration)). This result agrees with the fact that the mass-transfer limitation is low (see previous part) and it suggests that in the range of values tested, the increase in gas velocity does not improve the performances of the process.

Finally, the ozone inlet concentration was increased up to $30 \mathrm{~g} . \mathrm{m}^{-3}$. It implies an extra cost to produce ozone (OPEX), but it clearly improves the removal of toluene $\left(52.6 \%\right.$ at $10 \mathrm{~g}^{-\mathrm{m}^{-3}}$ ozone inlet concentration and $81.9 \%$ at $30 \mathrm{~g} \cdot \mathrm{m}^{-3}$ ). At the same time, the length of the reactor remains almost constant whatsoever the ozone outlet concentration because the rate of ozone decomposition is improved at high concentration and compensates the extra ozone to eliminate. These results highlight that increasing the ozone inlet concentration is the best way to improve toluene removal.

\subsubsection{Towards higher removal efficiencies of toluene}

According to the previous results of the predictive simulations, the best identified operating conditions are a temperature of $90^{\circ} \mathrm{C}$, a gas velocity of $0.010 \mathrm{~m} \cdot \mathrm{s}^{-1}$ and an inlet ozone concentration of $30 \mathrm{~g} \cdot \mathrm{m}^{-3}$. In these conditions, the removal of toluene was up to $81.9 \%$ with a $0.21 \mathrm{~m}$ reactor length. Such a removal of toluene may not be enough to match with the legislation about the rejection of VOC in air. That is why, some simulations were run aiming to remove $88 \%$ of toluene. To fulfill this aim, it needed $42 \mathrm{~g} . \mathrm{m}^{-3}$ of ozone inlet concentration and a $0.21 \mathrm{~m}$ reactor length and in that case almost full removal of ozone was also achieved. For a lower ozone removal (97.1\% of removal, $1.3 \mathrm{~g} . \mathrm{m}^{-3}$ of ozone at the outlet), the reactor length was almost twice as small $(0.11 \mathrm{~m})$ but the ozone inlet concentration was slightly higher $\left(46\right.$ g.m $\left.{ }^{-3}\right)$. In both cases, the ozone inlet concentration is high that may be a crippling for industrial implementation due to the fact that ozone generation is expensive. 
To keep a high toluene removal $(88 \%)$ but with a lower ozone inlet concentration, the reactor was split into two parts of equal length with ozone replenishment towards its initial value at the beginning of the second part of the reactor. The mixing time between the ozone flow for replenishment and the process flow is neglected. Indeed, a high mixing efficiency would be expected regarding the tortuosity of the catalytic support, which is another benefit of opencell foam compared to honeycomb monoliths (Hutter et al., 2010). The concentration profile of toluene and ozone along the reactor are given Fig. $\mathbf{5}$ as well as the rates of elimination of toluene and ozone. It clearly illustrates the benefit of ozone replenishment in the middle of the reactor which improves the rate of toluene oxidation. With this two-parts design, the reactor length is $0.15 \mathrm{~m}$ which is $36 \%$ higher than for a one-part reactor $(0.11 \mathrm{~m})$ but the ozone inlet concentration is $18 \mathrm{~g} \cdot \mathrm{m}^{-3}$ (actually, $34.5 \mathrm{~g} \cdot \mathrm{m}^{-3}$ for the overall reactor taking into account the replenishment in the middle of the reactor) which is clearly lower than for a one-part reactor (18\% of difference). In both cases, the ozone outlet concentration is the same $\left(1.3 \mathrm{~g} \cdot \mathrm{m}^{-3}\right)$. These results highlight that a compromise needs to be found between the energy necessary for ozone generation and the length of the reactor. A cost analysis would now be necessary to find the best reactor design and operating conditions. The deactivation of the catalyst was not considered in this study, using fresh catalytic glass foams. It has to be evaluated in a further work because it is a key point for industrial applications. Depending on the price and availability of ruthenium, regeneration, if technically feasible, can be envisaged because it facilitates extended use of the catalyst, minimizes the use of new raw materials, and reduces the need for ultimate recovery or disposal. 
a)

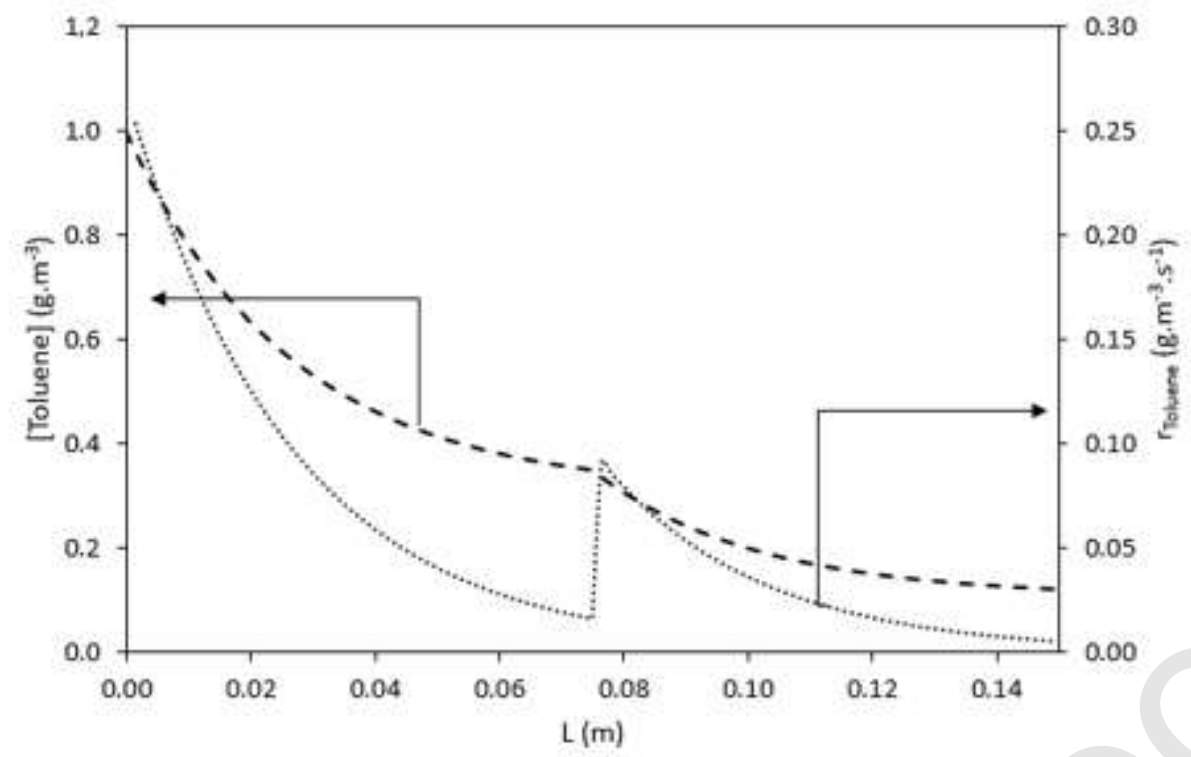

b)

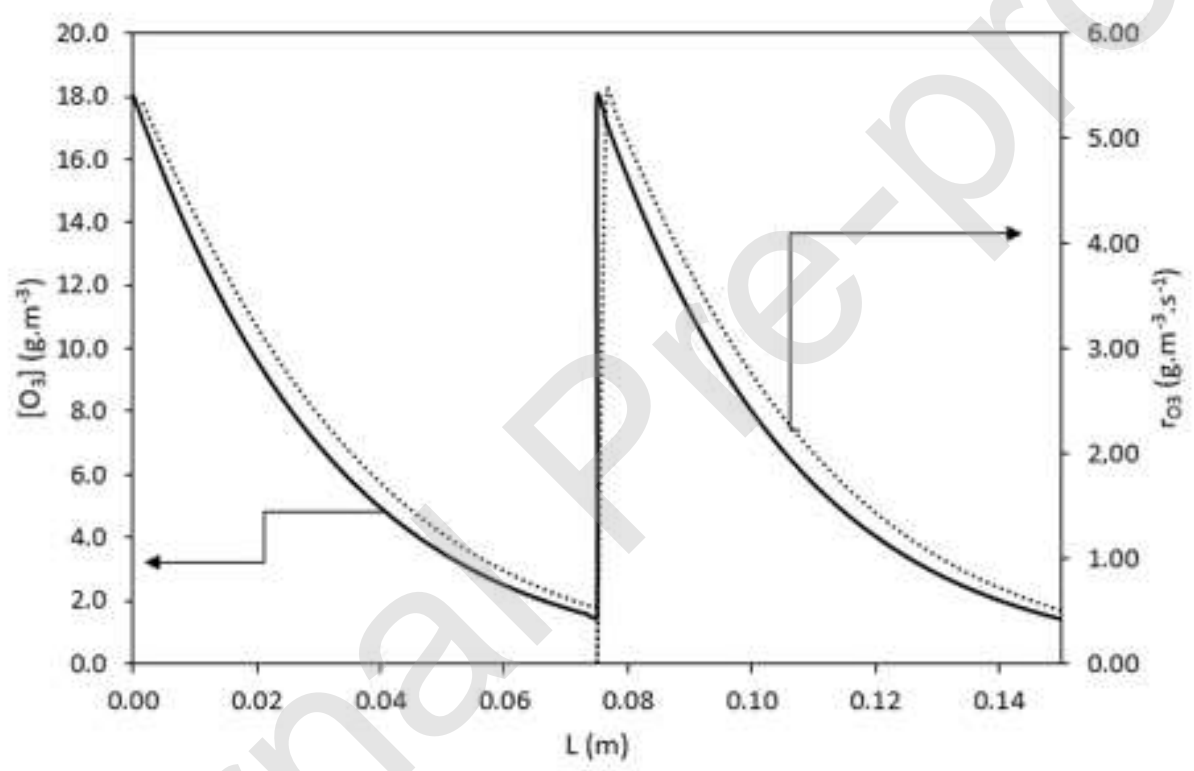

Fig. 5 - Concentration and rate of removal profiles for the simulations with a two-parts reactor with ozone replenishment $\left.\left(T=90^{\circ} \mathrm{C}, \mathrm{v}=0.01{\mathrm{~m} . \mathrm{s}^{-1}}^{-1}[\text { Toluene }]_{\text {inlet }}=1.0 \mathrm{g.m} \mathrm{m}^{-3}\right)-\mathrm{a}\right)$ Toluene - b) Ozone

\section{Conclusion}

Catalytic ozonation was performed with a glass foam support impregnated with zerovalent ruthenium nanoparticles aiming at $0.1 \mathrm{wt} . \%$. The efficiency of the catalytic glass foam was first experimentally proved. Based on the experimental results about toluene and ozone removal in function of the temperature, gas velocity and inlet ozone concentration, an accurate model with a Langmuir-Hinshelwood kinetic mechanism and mass transfer 
limitations was developed and adjusted. This model demonstrates that mass-transfer limitation remains limited even at a low superficial velocity of $0.011 \mathrm{~m} \mathrm{~s}^{-1}$, probably due to the high tortuosity of the support. Besides, the results highlight that competitive effects between ozone and toluene remain limited for ozone concentration and toluene concentration roughly lower than 10 g.m $\mathrm{m}^{-3}$ and 3-4 g.m $\mathrm{m}^{-3}$, respectively. Thus, for lower concentrations, the ozone and toluene apparent decomposition kinetics follow a first-order in regards of $\mathrm{O}_{3}$ and a second order in regards of $\mathrm{O}_{3}$ and toluene, respectively.

Predictive simulations were finally carried out to optimize the removal of toluene. The positive influence of high temperature and high ozone inlet concentration was clearly highlighted (smaller reactor and higher removal of toluene). To reach $88 \%$ of toluene removal to meet the regulation relative to industrial VOC emissions (with an inlet concentration of 1.0 g. $\mathrm{m}^{-3}$ ), two solutions were identified with different advantages and drawbacks according to the length of the reactor and ozone generation: (i) a one-part reactor of $0.11 \mathrm{~m}$ with high ozone inlet concentration (46 g. $\mathrm{m}^{-3}$ ) or (ii) a two-parts reactor of $0.15 \mathrm{~m}$ length with ozone replenishment at the middle (overall ozone concentration of $34.5 \mathrm{~g} \cdot \mathrm{m}^{-3}$ ). All these results emphasize the complexity of the process, which involves antagonist aims. Indeed, the toluene removal efficiency is mostly sensitive to the ozone concentration. Nonetheless, a high residence time is required to fully remove the ozone introduced. Thus, the addition of an ozone destructor would be a pertinent solution to remove the ozone residual and to limit the size of the reactor. Process scale-up would now be necessary to validate the results of the simulations.

Declaration of interest: none

\section{Acknowledgments}

The authors thank the SATT Ouest Valorisation for financial support (Maturation project DV Z433). This publication is (partially) supported by the European Union through the European Regional Development Fund (ERDF), the Ministry of Higher Education and Research, the French region of Brittany and Rennes Métropole. The authors also thank Loïc Joanny for SEM analyses (ScanMAT - UMS 2001). 


\section{References}

Aghbolaghy, M.; Soltan, J.; Chen, N., 2018. Low temperature catalytic oxidation of binary mixture of toluene and acetone in the presence of ozone. Catal. Let. 148, 3431-3444. DOI: $10.1007 / \mathrm{s} 10562-018-2536-8$

Aguirre, A.; Chandra, V.; Peters, E.A.J.F.; Kuipers, J.A.M.; Neira D’Angelo, M.F., 2020. Open-cell foams as catalyst support: A systematic analysis of the mass transfer limitations. Chem. Eng. J. 393, 124656. DOI: 10.1016/j.cej.2020.124656

Axet, M.R.; Philippot, K., 2020. Catalysis with Colloidal Ruthenium Nanoparticles. Chem. Rev. 120, 1085-1145. DOI: 10.1021/acs.chemrev.9b00434

Bedia, J.; Rosas, J.M.; Rodriguez-Mirasol, J.; Cordero, T., 2010. Pd supported on mesoporous activated carbons with high oxidation resistance as catalysts for toluene oxidation, Appl. Catal. B. Environ. 94, 8-18. DOI: 10.1016/j.apcatb.2009.10.015

Behar, S.; Gomez-Mendoza, N-A.; Gomez-Garcia, M-A.; Swierczynski, D.; Quignard, F.; Tanchoux, N., 2015. Study and modelling of kinetics of the oxidation of VOC catalyzed by nanosized $\mathrm{Cu}-\mathrm{Mn}$ spinels prepared via alginate route. Appl. Catal. A: Gen. 505, 203-210. DOI: 10.1016/j.apcata.2014.12.021

Bianchi, E.; Groppi, G.; Schwieger, W.; Tronconi, E.; Freund, H., 2015. Numerical simulation of heat transfer in the near-wall region of tubular reactors packed with metal opencell foams. Chem. Eng. J. 264, 268-279. DOI: 10.1016/j.cej.2014.11.055

Biard, P-F.; Bouzaza, A.; Wolbert, D., 2007. Photocatalytic Degradation of Two Volatile Fatty Acids in an Annular Plug-Flow Reactor; Kinetic Modeling and Contribution of Mass Transfer Rate. Environ. Sci. Technol. 41, 2908-2914. DOI: 10.1021/es062368n

Biard, P-F.; Couvert, A.; Denicourt, A.; Roucoux, A.; Lebullenger, R., 2017. Nanoparticules métalliques supportées sur un support en mousse de verre et utilisations pour la catalyse de réactions chimiques, WO2017064418A1.

Birdsall, C.M.; Jenkins, A.C., Spadinger, E., 1952. Iodometric determination of ozone. Anal. Chem. 24(4), 662-664. DOI: 10.1021/ac60064a013 
Bracconi, M.; Ambrosetti, M.; Maestri, M.; Groppi, G.; Tronconi, E., 2018. A fundamental investigation of gas/solid mass transfer in open-cell foams using a combined experimental and CFD approach. Chem Eng. J. 352, 558-571. DOI: 10.1016/j.cej.2018.07.023

Changsuphan, A.; Wahab, M.I.B.A.; Kim Oanh. N.T., 2012. Removal of benzene by ZnO nanoparticles coated on porous adsorbents in presence of ozone and UV. Chem. Eng. J. 181182, 215-221. DOI:10.1016/J.CEJ.2011.11.064

Einaga, H.; Futamura, S., 2007. Catalytic Oxidation of Benzene with Ozone over Mn Ion Exchanged Zeolites. Catal. Commun. 8, 557-560. DOI: 10.1016/j.catcom.2006.07.024

Einaga, H.; Teraoka, Y.; Ogata. A., 2013. Catalytic oxidation of benzene by ozone over manganese oxides supported on USY zeolite. J. Catal. 305, 227-237. DOI: 10.1016/j.jcat.2013.05.016

Giani, L.; Groppi, G.; Tronconi, E., 2005. Mass-Transfer Characterization of Metallic Foams as Supports for Structured Catalysts. Ind. Eng. Chem. Res. 44(14), 4993-5002. DOI: 10.1021/ie0490886

Green, D.W.; Perry, R.H. Perry's chemical engineers' handbook. The McGraw-Hill Companies, Inc. Eight Edition (2008).

Groppi, G.; Giani, L.; Tronconi, E., 2007. Generalized Correlation for Gas/Solid MassTransfer Coefficients in Metallic and Ceramic Foams. Ind. Eng. Chem. Res. 46, 3955-3958. DOI: $10.1021 / \mathrm{ie} 061330 \mathrm{~g}$

Guo, H.; Lee, S.C.; Chan, L.Y.; Li, W.M., 2004. Risk assessment of exposure to volatile organic compounds in different indoor environments. Environ. Res. 94, 57-66. DOI: 10.1016/S0013-9351(03)00035-5

He, C.; Cheng, J.; Zhang, X.; Douthwaite, M.; Pattisson, S.; Hao, Z., 2019. Recent Advances in the Catalytic Oxidation of Volatile Organic Compounds: A Review Based on Pollutant Sorts and Sources, Chem. Rev. 119, 4471-456. DOI: 10.1021/acs.chemrev.8b00408

$\mathrm{Hu}, \mathrm{C}$, 2011. Catalytic combustion kinetics of acetone and toluene over $\mathrm{Cu}_{0.13} \mathrm{Ce}_{0.87} \mathrm{O}_{y}$ catalyst. Chem. Eng. J. 168, 1185-1192. DOI: 10.1016/j.cej.2011.02.006 
Hu, M.; Yao, Z.; Hui, K.N.; Hui, K.S., 2017. Novel mechanistic view of catalytic ozonation of gaseous toluene by dual-site kinetic modelling, Chem. Eng. J. 308, 710-718. DOI: 10.1016/j.cej.2016.09.086

Huang, B.; Lei, C.; Wei, C.; Zeng, G., 2014. Chlorinated volatile organic compounds (ClVOCs) in environment - sources, potential human health impacts, and current remediation technologies. Environ. Int. 71, 118-138. DOI: 10.1016/j.envint.2014.06.013

Huang, H.; Ye, X.; Huang, W.; Chen, J.; Xu, Y.; Wu, M.; Shao, Q.; Peng, Z.; Ou, G.; Shi, J.; Feng, X.; Feng, Q.; Huang, H.; Hu, P.; Leung. D.Y.C., 2015. Ozone-catalytic oxidation of gaseous benzene over $\mathrm{MnO}_{2} / \mathrm{ZSM}-5$ at ambient temperature: catalytic deactivation and its suppression. Chem. Eng. J. 264, 24-31. DOI: 10.1016/j.cej.2014.11.072

Hutter, C.; Allemann, C.; Kuhn, S.; Rudolf von Rohr, Ph., 2010. Scalar transport in a milliscale metal foam reactor. Chem. Eng. Sci. 65, 3168-3178. DOI: 10.1016/j.ces.2010.02.002

Incera Garrido, G.; Patcas, F.C.; Lang, S.; Kraushaar-Czarnetzki, B., 2008. Mass transfer and pressure drop in ceramic foams: A description for different pore sizes and porosities. Chem. Eng. Sci. 63, 5202-5217. DOI: 10.1016/j.ces.2008.06.015

Jia, J.; Zhang, P.; Chen, L., 2016. Catalytic decomposition of gaseous ozone over manganese dioxides with different crystal structure. Appl. Catal. B. Environ. 189, 210-218. DOI: 10.1016/j.apcatb.2016.02.055

Ladi, F.; 2016. Characterization of foam catalysts as packing for tubular reactors. Chem. Eng. \& Process. Proc. Int. 105, 1-9. DOI: 10.1016/j.cep.2016.04.001

Lebedeva, A.; Albuquerque, B.L.; Domingos, J.B.; Lamonier, J.-F.; Giraudon, J.-M.; Lecante, P.; Denicourt-Nowicki, A.; Roucoux, A. 2019. Ruthenium Trichloride Catalyst in Water: Ru Colloids versus Ru Dimer Characterization Investigations. Inorg. Chem. 58, 4141-4151. DOI: 10.1021/acs.inorgchem.8b03144

Lejeune, A.; Cabrol, A.; Lebullenger, R.; Denicourt-Nowicki, A.; Roucoux, A.; Szymczyk, A.; Couvert, A.; Biard, P.F.; 2020a. Development of a sustainable heterogeneous catalyst based on an open-cell glass foam support: application in gas-phase ozone decomposition. ACS Sus. Chem. Eng. 8, 2854-2864. DOI: 10.1021/acs.iecr.0c02447 
Lejeune, A.; Cabrol, A.; Lebullenger, R.; Denicourt-Nowicki, A.; Roucoux, A.; Couvert, A.; Biard, P.F., 2020b. Novel and sustainable catalytic ruthenium-doped glass-foam for thermocatalytic oxidation of volatile organic compounds: an experimental and modeling study, Ind. Eng. Chem. Res. 59, 14758-14766. DOI: 10.1021/acs.iecr.0c02447

Lerner, J.E.C.; Sanchez, E.Y.; Sambeth, J.E.; Porta, A.A., 2012. Characterization and health risk assessment of VOCs in occupational environments in Buenos Aires, Argentina. Atmos. Environ. 55, 440-447. DOI:10.1016/J.ATMOSENV.2012.03.041

Liotta, L.F., 2010. Catalytic oxidation of volatile organic compounds on supported noble metals. Appl. Catal B. Environ. 100, 403-412. DOI: 10.1016/j.apcatb.2010.08.023

Massman, W.J., 1998. A review of molecular diffusivities of $\mathrm{H}_{2} \mathrm{O}, \mathrm{CO}_{2}, \mathrm{CH}_{4}, \mathrm{CO}, \mathrm{O}_{3}, \mathrm{SO}_{2}$, $\mathrm{NH}_{3}, \mathrm{~N}_{2} \mathrm{O}, \mathrm{NO}$, and $\mathrm{NO}_{2}$ in air, $\mathrm{O}_{2}$ and $\mathrm{N}_{2}$ near STP. Atmos. Env.32, 1111-1127. DOI: $10.1016 / \mathrm{S} 1352-2310(97) 00391-9$

Meille, V., 2006. Review on methods to deposit catalysts on structured surfaces. Appl. Catal. A. Gen. 315, 1-17. DOI: 10.1016/j.apcata.2006.08.031

Rauchdi, M.; Ait Ali, M.; Roucoux, A.; Denicourt-Nowicki, A.; 2018. Novel access to verbenone via ruthenium nanoparticles-catalyzed oxidation of $\alpha$-pinene in neat water. Appl. Catal. A. Gen. 550, 266-273. DOI: 10.1016/j.apcata.2017.11.016

Reed, C.; Lee, Y-K.; Ted Oyama, S., 2006. Structure and Oxidation State of Silica-Supported Manganese Oxide Catalysts and Reactivity for Acetone Oxidation with Ozone. J. Phys. Chem. B. 110, 4207-4216. DOI: 10.1021/jp054288w

Rezaei, E.; Soltan, J., 2012. Low temperature oxidation of toluene by ozone over $\mathrm{MnOx} / \gamma-$ alumina and MnOx/MCM-41 catalysts. Chem. Eng. J. 198-199, 482-490. DOI: 10.1016/j.cej.2012.06.016

Rezaei, E.; Soltan, J.; Chen. N., 2013. Catalytic oxidation of toluene by ozone over alumina supported manganese oxides: effect of catalyst loading. Appl. Catal. B. Environ. 136-137, 239-247. DOI: 10.1016/j.apcatb.2013.01.061

Richardson, J.T.; Peng, Y.; Remue, D., 2000. Properties of ceramic foam catalyst supports: pressure drops. Appl. Catal. A. Gen. 204, 19-32. DOI: 10.1016/S0926-860X(00)00508-1 
Sano, T.; Negishi, N.; Sakai, E.; Matsuzawa, S., 2006. Contributions of Photocatalytic/Catalytic Activities of $\mathrm{TiO}_{2}$ and $\gamma-\mathrm{Al}_{2} \mathrm{O}_{3}$ in Nonthermal Plasma on Oxidation of Acetaldehyde and CO. J. Mol. Catal. A: Chem. 245, 235-241. DOI: 10.1016/j.molcata.2005.10.002

Sekiguchi, K.; Kurita, Y.; Sankoda, K.; Namiki, N.; Yasui, F.; Tamura, H.; 2017. Ozone catalytic oxidation of gaseous toluene over $\mathrm{MnO}_{2}$-based ozone decomposition catalysts immobilized on a nonwonen fabric. Aero. \& Air Qual. Res. 17, 2110-2118. DOI: 10.4209/aaqr.2017.01.0045.

Shahzad Kamal, M.; Razzak, S.A.; Hossain, M.M., 2016. Catalytic oxidation of volatile organic compounds (VOCs) - A review. Atm. Environ. 140, 117-134. DOI: 10.1016/j.atmosenv.2016.05.031

Stemmet, C.P.; Meeuwse, M.; Van der Schaaf, J.; Kuster, B.F.M.; Schouten, J.C.; 2007. Gasliquid mass transfer and axial dispersion in solid foam packagings. Chem. Eng. Sci. 62, 54445450. DOI: 10.1016/j.ces.2007.02.016

Stoyanova, M.; Konova, P.; Nikolov, P.; Naydenov, A.; Christoskova, S.; Mehandjiev. D., 2006. Alumina-supported nickel oxide for ozone decomposition and catalytic ozonation of CO and VOCs. Chem. Eng. J. 122(1-2), 41-46. DOI: 10.1016/j.cej.2006.05.018

Watson, A.; Maxwell, A.; Williams, J.; 2009. Ruthenium Catalyzed Oxidation of Alcohols into Amides. Org. Lett. 11 (12), 2667-2670. DOI: 10.1021/o1900723v

Xi, Y.; Reed, C.; Lee, Y-K.; Ted Oyama, S., 2005. Acetone Oxidation Using Ozone on Manganese Oxide Catalysts. J. Phys. Chem. B. 109, 17587-17596. DOI: 10.1021/jp052930g

Xu, H.; Yan, N.; Qu, Z.; Liu, W.; Mei, J.; Huang, W.; Zhao, S., 2017. Gaseous heterogeneous catalytic reactions over Mn-based oxides for Environmental applications: A critical review. Environ. Sci. Technol. 51, 8879-8892. DOI: 10.1021/acs.est.6b06079 